\title{
Flow and nutrient dynamics in a subterranean estuary (Waquoit Bay, MA, USA): Field data and reactive transport modeling
}

\author{
Claudette Spiteri $^{\mathrm{a}, *}$, Caroline P. Slomp ${ }^{\mathrm{a}}$, Matthew A. Charette ${ }^{\mathrm{b}}$, \\ Kagan Tuncay ${ }^{\mathrm{c}}$, Christof Meile ${ }^{\mathrm{d}}$ \\ ${ }^{a}$ Department of Earth Sciences-Geochemistry, Faculty of Geosciences, Utrecht University, P.O. Box 80021, 3508 TA Utrecht, The Netherlands \\ ${ }^{\mathrm{b}}$ Department of Marine Chemistry and Geochemistry, Woods Hole Oceanographic Institution, MA 02543, USA \\ ${ }^{\mathrm{c}}$ Faculty of Engineering, Middle East Technical University, Kalkanli, Güzelyurt, Cyprus, Mersin 10, Turkey \\ d Department of Marine Sciences, University of Georgia, Athens, GA 30602-3636, USA
}

Received 19 November 2007; accepted in revised form 25 April 2008; available online 6 May 2008

\begin{abstract}
A two-dimensional (2D) reactive transport model is used to investigate the controls on nutrient $\left(\mathrm{NO}_{3}{ }^{-}, \mathrm{NH}_{4}{ }^{+}, \mathrm{PO}_{4}\right)$ dynamics in a coastal aquifer. The model couples density-dependent flow to a reaction network which includes oxic degradation of organic matter, denitrification, iron oxide reduction, nitrification, $\mathrm{Fe}^{2+}$ oxidation and sorption of $\mathrm{PO}_{4}$ onto iron oxides. Porewater measurements from a well transect at Waquoit Bay, MA, USA indicate the presence of a reducing plume with high $\mathrm{Fe}^{2+}, \mathrm{NH}_{4}^{+}$, DOC (dissolved organic carbon) and $\mathrm{PO}_{4}$ concentrations overlying a more oxidizing $\mathrm{NO}_{3}^{-}$-rich plume. These two plumes travel nearly conservatively until they start to overlap in the intertidal coastal sediments prior to discharge into the bay. In this zone, the aeration of the surface beach sediments drives nitrification and allows the precipitation of iron oxide, which leads to the removal of $\mathrm{PO}_{4}$ through sorption. Model simulations suggest that removal of $\mathrm{NO}_{3}{ }^{-}$through denitrification is inhibited by the limited overlap between the two freshwater plumes, as well as by the refractory nature of terrestrial DOC. Submarine groundwater discharge is a significant source of $\mathrm{NO}_{3}{ }^{-}$to the bay.
\end{abstract}

(C) 2008 Elsevier Ltd. All rights reserved.

\section{INTRODUCTION}

Coastal aquifers worldwide, in particular in areas strongly influenced by human activities, are increasingly becoming contaminated with nutrients from fertilizer and waste-water (Valiela et al., 1992). Discharge of this groundwater along beaches and through the seafloor is now recognized as an important transport pathway of nutrients to

\footnotetext{
${ }^{*}$ Corresponding author. Present address: Marine and Coastal Systems, Deltares (WL — Delft Hydraulics), P.O. Box 177, 2600 MH Delft, The Netherlands. Fax: +31 152858582 .

E-mail addresses: claudette.spiteri@deltares.nl (C. Spiteri), slomp@geo.uu.nl (C.P. Slomp), mcharette@whoi.edu (M.A. Charette), ktuncay@gmail.com (K. Tuncay), cmeile@uga.edu (C. Meile).
}

coastal waters (e.g., Burnett et al., 2006). The chemical composition of this submarine groundwater discharge (SGD) not only depends on the landward freshwater source(s) but also on the rates of groundwater flow and the biogeochemical reactions that occur in the part of the coastal aquifer where freshwater and seawater interact ("subterranean estuary"; Moore, 1999). Owing to the difficulties in sampling coastal aquifers and the complex flow structure in subterranean estuaries (e.g., Burnett et al., 2006), our quantitative understanding of nutrient dynamics in these systems is still limited.

The biogeochemistry of nutrients $\left(\mathrm{NO}_{3}{ }^{-}, \mathrm{NH}_{4}{ }^{+}\right.$and dissolved inorganic phosphate, $\mathrm{PO}_{4}$ ) in subterranean estuaries and the groundwater nutrient fluxes to coastal waters are strongly affected by the redox conditions of the freshwater and seawater (e.g., Slomp and Van Cappellen, 2004; 
Spiteri et al., 2008). In groundwater systems, $\mathrm{NO}_{3}^{-}$supplied either by infiltrating water or produced through nitrification (Nowicki et al., 1999) can be removed by denitrification under anoxic conditions. However, field studies often report only limited $\mathrm{NO}_{3}{ }^{-}$removal prior to discharge to coastal waters. This is primarily attributed to a lack of labile dissolved organic matter (e.g., Slater and Capone, 1987; DeSimone and Howes, 1996) or high groundwater velocities (Capone and Slater, 1990; Giblin and Gaines, 1990) which do not allow for significant biogeochemical transformations in the subterranean estuary. Organic matter degradation is often the major source of both groundwater $\mathrm{NH}_{4}{ }^{+}$and $\mathrm{PO}_{4}$. Under oxic conditions, $\mathrm{NH}_{4}{ }^{+}$is effectively removed through nitrification while phosphorus $(\mathrm{P})$ is attenuated through sorption onto iron and aluminum oxides. The formation of iron oxide at the freshwater-seawater interface is driven by the oxidation of $\mathrm{Fe}^{2+}$ as it is transported through oxic surface beach sediments (Charette and Sholkovitz, 2002). Other studies (Davison and Seed, 1983; Spiteri et al., 2006) suggest that the $\mathrm{pH}$ increase from freshwater to seawater can also play an important role in the precipitation of iron oxides in coastal sediments.

The contamination of many coastal aquifers by nitrogen $(\mathrm{N})$ of anthropogenic origin, the limited loss by denitrification, in combination with efficient $\mathrm{P}$ removal may lead to SGD with an N:P ratio higher than the Redfield ratio of phytoplankton ( $\mathrm{N}: \mathrm{P}=16: 1)$. This can potentially drive the N-limited coastal primary production to P-limitation (Slomp and Van Cappellen, 2004), causing a shift in the ecological community structure. In Waquoit Bay, increased nitrogen input to the watershed, primarily through atmospheric deposition, fertilizers and wastewater, has lead to an increase in the nutrient loading in its subestuaries (Valiela et al., 1992, 2002). The resulting alterations in these aquatic systems include greater primary productivity by phytoplankton, recurrent bottom anoxia and loss of eelgrass abundance (Valiela et al., 1992).

Recent literature on SGD has mostly focused on the location of discharge hotspots and the quantification of discharge rates using a suite of different methods (e.g., Giblin and Gaines, 1990; Corbett et al., 2000; Sholkovitz et al., 2003; Breier et al., 2005; Michael et al., 2005; Stieglitz, 2005; Moore, 2006). Fewer studies (e.g., Krest et al., 2000; Charette et al., 2001; Hwang et al., 2005; Shellenbarger et al., 2006) have estimated the magnitude of nutrient fluxes through SGD, which is generally done through simple multiplication of the measured SGD rates with the average nutrient concentrations in groundwater. If not done at the point of seepage, this approach does not account for any transformation/removal processes that might alter the biogeochemical fate of nutrients as groundwater travels through the subterranean estuary (e.g., Beck et al., 2007).

The aim of this study is to attain a better understanding of nutrient dynamics in subterranean estuaries and the implications for SGD of nutrients. We first analyze the porewater concentration profiles for various chemical species along a transect at the head of Waquoit Bay, MA,
USA. We then use a two-dimensional (2D) density-dependent reactive transport model (RTM) to simulate (a) the tidally averaged flow dynamics and (b) the main biogeochemical reactions affecting nitrogen and phosphorus. This allows us to identify and quantify the removal and transformation processes affecting $\mathrm{NO}_{3}{ }^{-}, \mathrm{NH}_{4}{ }^{+}$and $\mathrm{PO}_{4}$ in the coastal aquifer and estimate the resulting rates of SGD of these nutrients. Finally, the response of the system to changes in (a) the reactivity of the terrestrial organic matter (b) the landward source concentration of phosphorus and (c) the flow dynamics as a result of sealevel rise is investigated.

\section{STUDY SITE}

Waquoit Bay is a shallow estuary, approximately $1220 \mathrm{~m}$ wide and $3350 \mathrm{~m}$ long, located on the southern shoreline of Cape Cod (Fig. 1). It is part of the Waquoit Bay National Estuarine Research Reserve (WBNERR) and has been used as a field site in various previous scientific investigations, including physical oceanographical, hydrological, geological, biological and geochemical studies (e.g., Valiela et al., 1992; Cambareri and Eichner, 1998; Charette and Sholkovitz, 2002; Testa et al., 2002; Sholkovitz et al., 2003; Talbot et al., 2003). The sedimentary deposits on Cape Cod generally consist of outwash gravel, sand, silt, and occasional lacustrine deposits of silts and clays (Oldale, 1976, 1981). The aquifer is $100-120 \mathrm{~m}$ thick and is underlain by less permeable deposits of basal till and bedrock (LeBlanc et al., 1986). Further details on the stratigraphy of the Cape Cod aquifer can be found in Cambareri and Eichner (1998) and Mulligan and Charette (2006).

The bay has an average depth of $1 \mathrm{~m}$ and a tidal range of $\sim 1.1 \mathrm{~m}$ (Mulligan and Charette, 2006). The head of bay is the smallest of the seven sub-watersheds that border Waquoit Bay and has a human population density of 190 persons $\mathrm{km}^{-2}$. It covers an area of $0.76 \mathrm{~km}^{2}$ extending approximately $2 \mathrm{~km}$ north with a maximum width of about $1 \mathrm{~km}$ between Childs River and Quashnet River (Masterson and Walter, 2000; Fig. 1). Three freshwater ponds, Bog, Bourne and Caleb Pond (Fig. 1), also drain at the northern end of the bay. Hydrogeological cross sections along the Waquoit Bay watershed reveal a thinning in the depth of the upper unconfined aquifer at the head of bay to $\sim 11 \mathrm{~m}$ (Cambareri and Eichner, 1998), where it consists of relatively homogeneous medium to fine sands, bounded by a less permeable layer of fine sand, silt and clay (Masterson et al., 1997). In the upper aquifer, the range of hydraulic conductivity values obtained from slug tests varies between $3.7 \times 10^{-4}$ and $1.7 \times 10^{-3} \mathrm{~m} \mathrm{~s}^{-1}$, with a geometric mean of $6 \times 10^{-4} \mathrm{~m} \mathrm{~s}^{-1}$ (Mulligan and Charette, 2006). The landward topography at the head of the bay is characterized by a low-lying valley in the middle of two large bluffs (Mulligan and Charette, 2006), which give rise to spatially variable groundwater velocities.

Due to the highly permeable soils and coarse-grained sands on Cape Cod, surface runoff is rather low, while groundwater discharge into streams, rivers and the bay is relatively high. SGD in the seven watersheds of Waquoit 


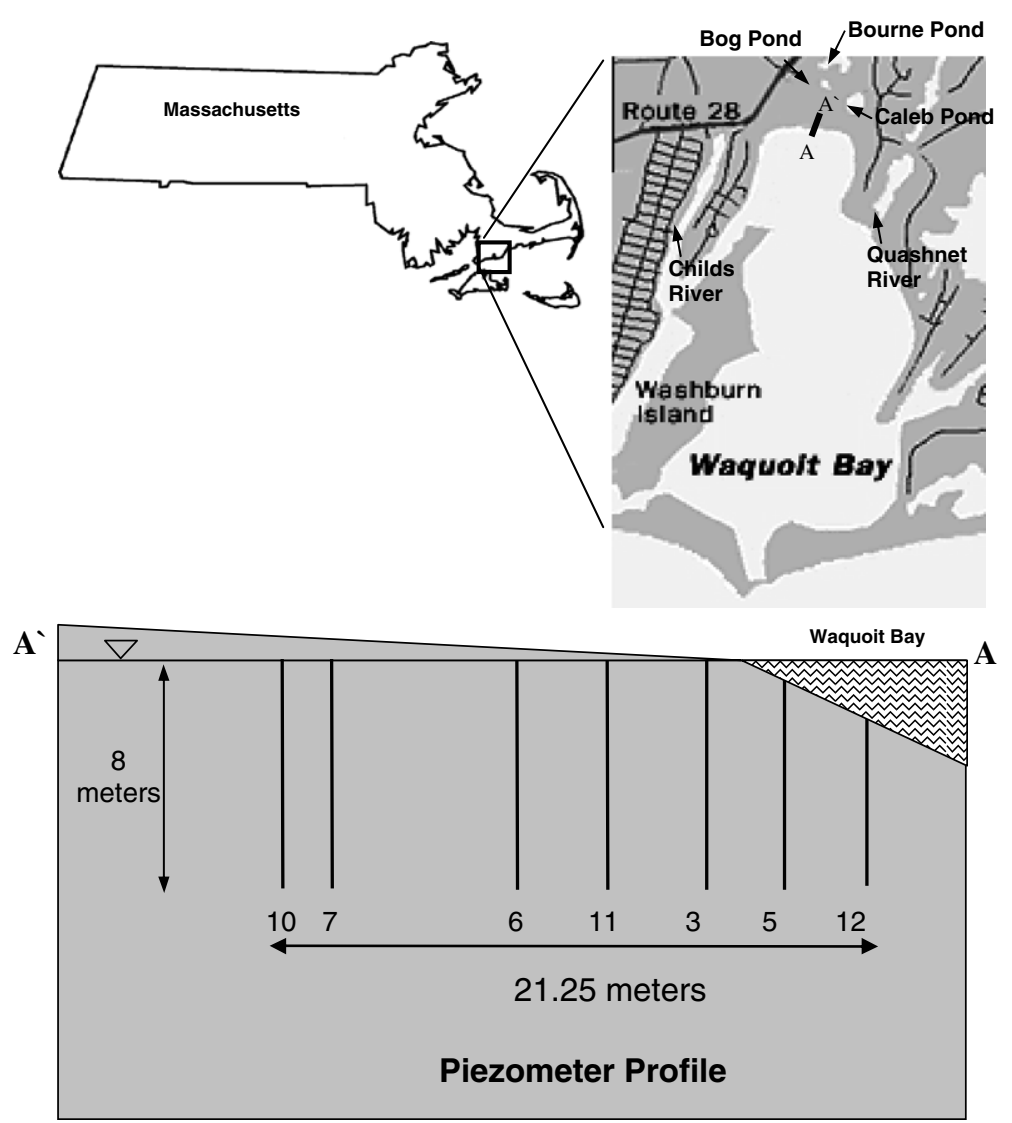

Fig. 1. Map of Waquoit Bay, showing the position of piezometer transect $\left(\mathrm{A}^{\prime}-\mathrm{A}\right)$ perpendicular to the shoreline at the head of the bay, the three ponds and two rivers that flow into the bay. Note that the distance between PZ-10 and PZ-7 is $2 \mathrm{~m}$ whereas that between PZ-7 and PZ-6 is $7.25 \mathrm{~m}$. The rest of the piezometers are equidistant, at $3 \mathrm{~m}$ apart.

Bay accounts for $0.028 \mathrm{~m}^{3} \mathrm{~s}^{-1}$ or $34 \%$ of the freshwater input to the bay. The rest is derived from direct precipitation (11\%; amounting to $\sim 114 \mathrm{~cm} \mathrm{yr}^{-1}$ on the Upper Cape) and surface runoff (55\%) (Cambareri and Eichner, 1998). Assuming a freshwater discharge rate $\left(Q_{\mathrm{f}}\right)$ of $0.028 \mathrm{~m}^{3} \mathrm{~s}^{-1}$ and a tidally driven circulation rate $\left(Q_{\mathrm{t}}\right)$ of $0.013 \mathrm{~m}^{3} \mathrm{~s}^{-1}$ (Michael, 2004), the calculated flow ratio $\left(Q_{\mathrm{f}} / Q_{\mathrm{t}}\right)$ is $\sim 2.0$. Following the classification of subterranean estuaries presented in Robinson et al. (2007), with a flow ratio $>1$, this subterranean estuary is "stratified". This implies that the upper saline plume that may be present in addition to the classical salt-wedge, is of minor importance.

\section{FIELD MEASUREMENTS}

A 22-m transect, consisting of seven piezometers perpendicular to the shoreline was installed in the low-lying region at the head of the bay (Fig. 1). Porewater samples were taken using a stainless steel drive point piezometer system (Retract-A-Tip from AMS (Idaho USA), Inc.; Charette and Allen, 2006). These non-conventional piezometers were used to sample groundwater at multiple depths with a sample interval of $0.45 \mathrm{~m}$ down to a depth of $8 \mathrm{~m}$. The sample depth resolution along the freshwater-seawater interface was further increased to $\sim 0.15 \mathrm{~m}$. Groundwater samples were brought to the surface through acid-cleaned Teflon or polypropylene tubing using a peristaltic pump and filtered through a $0.45 \mu \mathrm{M}$ Pall capsule filter to remove particulates. Measurements of sample $\mathrm{pH}$, salinity, conductivity, density and $\mathrm{O}_{2}$ were taken in the field using a YSI 600XLM multi-probe in a flow through cell. The samples were further analyzed for $\mathrm{NO}_{3}{ }^{-}+\mathrm{NO}_{2}{ }^{-}$(referred here to as $\mathrm{NO}_{3}{ }^{-}$only, which constitutes the major fraction), $\mathrm{NH}_{4}{ }^{+}, \mathrm{PO}_{4}$, dissolved organic carbon (DOC) and total dissolved $\mathrm{Fe}$ (TDFe), of which a major fraction is in the form of $\mathrm{Fe}^{2+}$ (Charette et al., 2005). Concentrations of nutrients were measured colorimetrically, using a Lachat nutrient auto-analyzer (Zellweger Analytics, QuickChem 8000 series). Analysis of TDFe was carried out on acidified samples ( $\mathrm{pH} 2$ ) using inductively coupled plasma mass spectrometry (ICP-MS), and inductively coupled plasma optical emission spectroscopy (ICP-OES) was used to analyze the major ions $\left(\mathrm{Ca}^{2+}, \mathrm{Mg}^{2+}, \mathrm{Na}^{+}, \mathrm{K}^{+}\right.$and $\left.\mathrm{Cl}^{-}\right)$. DOC was measured using a total organic carbon analyzer. Further details on the methods of analysis employed during four field campaigns (2002-2005) can found in Talbot et al. (2003), Charette et al. (2005) and Charette and Allen (2006). The time required for the high-resolution sampling of each piezometer was 4-8 h, and the entire transect was sampled over 7 days. Therefore, the porewater measurements are assumed representative of tidally averaged conditions. 


\section{REACTIVE TRANSPORT MODEL}

A 2D/3D finite element reactive transport model including density-dependent flow (Spiteri et al., 2008) is used to simulate the coupled flow and biogeochemistry in the coastal aquifer of Waquoit Bay. A schematic diagram of the model domain and the values of model parameters used in the simulations are given in Fig. 2a. In the model, we impose an impermeable (no flux) boundary condition at the top and bottom boundaries. The lower boundary represents the delimiting confining layer of the 11-m deep upper aquifer while the effect of recharge through the top boundary is assumed to be negligible. Although this is a simplifying assumption, the effect of the precipitation and infiltration in the near-shore area is not expected to alter the local flow regime significantly. The length of the model domain is chosen so that the steady-state saltwater wedge that develops does not interfere with the left freshwater boundary. Pressure is imposed on both the freshwater and seawater sides, while the effect of seasonal variation in freshwater discharge is not taken into account. Moreover, as model results are compared to tidally averaged field measurements, tidal pumping is not included in the model. The values of porosity $(\phi)$ and longitudinal dispersivity $\left(\alpha_{\mathrm{L}}\right)$ used in the simulations (Fig. 2a) are constrained by the modeling work of Michael et al. (2005) for the same bay, whereas the permeability $(\kappa)$ estimate of $7 \times 10^{-11} \mathrm{~m}^{2}$, equivalent to a hydraulic conductivity of $6.9 \times 10^{-4} \mathrm{~m} \mathrm{~s}^{-1}$, falls within the measured range of measured hydraulic conductivities (Michael et al., 2005). The value of transverse dispersivity $\left(\alpha_{\mathrm{T}}\right)$ is set by trial and error to $0.005 \mathrm{~m}$, to match the measured and modeled salinity profiles and the relatively sharp freshwater-saltwater interface. We assume a simplified, idealized, yet realistic representation of the local homogeneous flow regime and focus on the complexities that determine the biogeochemical dynamics in this subterranean estuary. An analysis of the ef- fect of small-scale variations in the flow dynamics on the biogeochemical behavior is beyond the scope of this study.

The chemical constituents considered include salt, $\mathrm{NO}_{3}{ }^{-}, \mathrm{NH}_{4}{ }^{+}, \mathrm{PO}_{4}$, adsorbed phosphate $\left(\mathrm{PO}_{4(\mathrm{ads})}\right)$, ferrous iron $\left(\mathrm{Fe}^{2+}\right)$, iron oxide $\left(\mathrm{Fe}(\mathrm{OH})_{3}\right)$, dissolved oxygen $\left(\mathrm{O}_{2}\right)$ and two fractions of dissolved organic carbon (a terrestrial, more refractory component, $\mathrm{DOC}_{1}$, and a marine labile fraction, $\mathrm{DOC}_{2}$ ). All chemical species, except for $\mathrm{PO}_{4(\mathrm{ads})}$

Table 1

Boundary concentrations at the freshwater and seawater side

\begin{tabular}{lll}
\hline Species $^{*}$ & $\begin{array}{l}\text { Boundary concentration- } \\
\text { freshwater side }\end{array}$ & $\begin{array}{l}\text { Boundary } \\
\text { concentration-seawater } \\
\text { side }\end{array}$ \\
\hline $\mathrm{Salt}$ & 0.2 & 26.2 \\
$\mathrm{NO}_{3}{ }^{-}$ & $0.5^{* *}$ & 0.0 \\
$\mathrm{NH}_{4}{ }^{+}$ & $0.15^{* *}$ & 0.03 \\
$\mathrm{PO}_{4}$ & $0.006^{* *}$ & 0.002 \\
$\mathrm{PO}_{4(\mathrm{ads})}$ & - & - \\
$(\mathrm{s})$ & & \\
$\mathrm{O}_{2}$ & $0.2^{* *}$ & 0.1 \\
$\mathrm{DOC}$ & $1.2^{* *}$ & - \\
$\mathrm{DOC}$ & 0.0 & 0.75 \\
$\mathrm{Fe}$ & $0.1^{* *}$ & 0.035 \\
$\mathrm{Fe}(\mathrm{OH})_{3}$ & - & - \\
$(\mathrm{s})$ & &
\end{tabular}

${ }^{*}$ Units for solutes are in $\mathrm{mmol} \mathrm{dm}{ }^{-3}$ pore water, denoted as $\mathrm{mM}$; solids are in $\mathrm{mmol} \mathrm{dm}{ }^{-3}$ solid, denoted as $\mathrm{mmol} \mathrm{dm} \mathrm{dm}^{-3}$; units for salt are $\%$.

** Introduced as solute plume sources; the solute concentrations outside the plumes are set to $0 \mathrm{mmol} \mathrm{dm}{ }^{-3}$ pore water. Depths of the sources plumes at the freshwater boundary are: $\mathrm{NO}_{3}{ }^{-} 6.5-$ $7.2 \mathrm{~m} ; \mathrm{NH}_{4}{ }^{+} 2.5-5.5 \mathrm{~m} ; \mathrm{PO}_{4} 1.0-3.5 \mathrm{~m} ; \mathrm{O}_{2} 6.5-7.2 \mathrm{~m} ; \mathrm{DOC}_{1} 1.0$ $3.0 \mathrm{~m} ; \mathrm{Fe}^{2+} 3.0-4.5 \mathrm{~m}$.

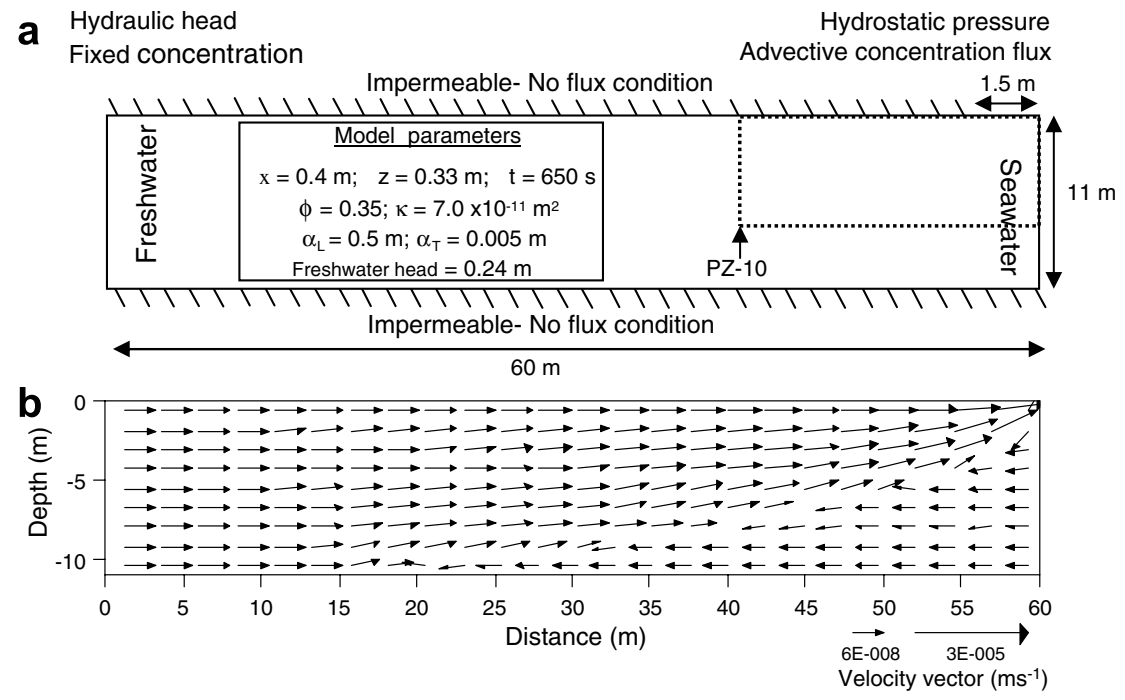

Fig. 2. Schematic diagram of model domain (a), including the set of model parameters and boundary conditions used in the simulations. The dotted box on the top right-hand side corner encloses the transect of geochemical field measurements $(\Delta x=$ space discretization in $x$-direction; $\Delta z=$ space discretization in $z$-direction; $\Delta t=$ time step; $\phi=$ porosity; $\alpha_{\mathrm{L}}=$ longitudinal dispersivity; $\alpha_{\mathrm{T}}=$ transverse dispersivity; $\kappa=$ permeability). Resultant velocity vector field (b) representing density-dependent flow in the coastal aquifer. 
Table 2

The reaction network and kinetic formulations used in the simulations

\begin{tabular}{|c|c|c|}
\hline Name & Reaction & Kinetic formulation \\
\hline Oxic degradation & $\begin{array}{l}\mathrm{DOC}^{(\mathrm{a}, \mathrm{b})}+x \mathrm{O}_{2}+(-y+2 z) \mathrm{HCO}_{3}^{-} \rightarrow \\
(x-y+2 z) \mathrm{CO}_{2}+y \mathrm{NH}_{4}^{+}+z \mathrm{HPO}_{4}^{2-} \\
+(x-y+2 z) \mathrm{H}_{2} \mathrm{O}\end{array}$ & $\begin{array}{l}\text { If } \mathrm{O}_{2}>\mathrm{kmo} 2 ; \text { Rate }=k_{\text {fox }}^{(\mathrm{c})}[\mathrm{DOC}] \\
\text { If } \mathrm{O}_{2}<\mathrm{kmo} 2 ; \text { Rate }=k_{\text {fox }}[\mathrm{DOC}] \frac{\left[\mathrm{O}_{2}\right]}{\left[\mathrm{kmo}^{2}\right]}\end{array}$ \\
\hline Denitrification & $\begin{array}{l}\mathrm{DOC}+0.8 x \mathrm{NO}_{3}^{-} \rightarrow 0.4 x \mathrm{~N}_{2}+(0.2 x-y+2 z) \mathrm{CO}_{2} \\
+(0.8 x+y-2 z) \mathrm{HCO}_{3}{ }^{-}+y \mathrm{NH}_{4}{ }^{+}+z \mathrm{HPO}_{4}{ }^{2-} \\
+(0.6 x-y+2 z) \mathrm{H}_{2} \mathrm{O}\end{array}$ & $\begin{array}{l}\text { If } \mathrm{O}_{2}<\mathrm{kmo} 2 \text { and } \mathrm{NO}_{3}{ }^{-}>\mathrm{kmno} \\
\text { Rate }=k_{\mathrm{fox}}[\mathrm{DOC}]\left(1-\frac{\left[\mathrm{O}_{2}\right]}{\mathrm{kmo}^{2}}\right) \\
\text { If } \mathrm{O}_{2}<\mathrm{kmo} 2 \text { and } \mathrm{NO}_{3}{ }^{-}>\mathrm{kmno} \\
\text { Rate }=k_{\text {fox }}[\mathrm{DOC}]\left(1-\frac{\left[\mathrm{O}_{2}\right]}{\mathrm{kmo}^{2}}\right) \frac{\mathrm{NO}_{3}^{-}}{\mathrm{kmo3}^{-}}\end{array}$ \\
\hline $\mathrm{Fe}(\mathrm{OH})_{3}$ reduction & $\begin{array}{l}\mathrm{DOC}+4 x \cdot \mathrm{Fe}(\mathrm{OH})_{3}+(7 x+y-2 z) \mathrm{CO}_{2} \rightarrow 4 x \cdot \mathrm{Fe}^{2+} \\
+(8 x+y-2 z) \mathrm{HCO}_{3}^{-}+y \mathrm{NH}_{4}^{+}+z \mathrm{HPO}_{4}^{2-} \\
+(3 x-y+2 z) \mathrm{H}_{2} \mathrm{O}\end{array}$ & $\begin{array}{l}\text { If } \mathrm{NO}_{3}{ }^{-}>\mathrm{kmno} 3 \text {; Rate }=0 \\
\text { If } \mathrm{NO}_{3}{ }^{-}<\mathrm{kmno} 3 \text { and } \mathrm{Fe}(\mathrm{OH})_{3}>\mathrm{kmfe} \text {; Rate } \\
=k_{\mathrm{fox}}[\mathrm{DOC}]\left(1-\frac{\left[\mathrm{O}_{2}\right]}{\mathrm{kmo}^{2}} \frac{\left[\mathrm{NO}_{3}^{-}\right]}{\mathrm{kmno}^{-}}\right) \\
\text {If } \mathrm{NO}_{3}{ }^{-}<\mathrm{kmno} 3 \text { and } \mathrm{Fe}(\mathrm{OH})_{3}>\mathrm{kmfe} ; \text { Rate } \\
=k_{\text {fox }}[\mathrm{DOC}]\left(1-\frac{\left[\mathrm{O}_{2}\right]}{\mathrm{kmo} 2} \frac{\left[\mathrm{NO}_{3}^{-}\right]}{\mathrm{kmno}^{-}}\right) \frac{\left[\mathrm{Fe}(\mathrm{OH})_{3}\right.}{[\mathrm{kmf}]}\end{array}$ \\
\hline $\begin{array}{l}\text { Nitrification } \\
\mathrm{Fe}^{2+} \text { oxidation } \\
\mathrm{P} \text { adsorption }\end{array}$ & $\begin{array}{l}\mathrm{NH}_{4}{ }^{+}+2 \mathrm{O}_{2}+2 \mathrm{HCO}_{3}{ }^{-} \rightarrow \mathrm{NO}_{3}{ }^{-}+2 \mathrm{CO}_{2}+3 \mathrm{H}_{2} \mathrm{O} \\
\mathrm{Fe}^{2+}+0.25 \mathrm{O}_{2}+2 \mathrm{HCO}_{3}{ }^{-}+0.5 \mathrm{H}_{2} \mathrm{O} \rightarrow \mathrm{Fe}(\mathrm{OH})_{3}+2 \mathrm{CO}_{2} \\
K_{\mathrm{d}}^{(\mathrm{d})} \cdot \frac{\varphi}{(1-\varphi)}=\frac{\left\lfloor\mathrm{PO}_{4(\mathrm{ads})}\right\rfloor}{\left[\mathrm{PO}_{4}\right]}\end{array}$ & $\begin{array}{l}\text { Rate }=k_{\text {nitri }}\left[\mathrm{NH}_{4}^{+}\right]\left[\mathrm{O}_{2}\right] \\
\text { Rate }=k_{\text {feox }}\left[\mathrm{Fe}^{2+}\right]\left[\mathrm{O}_{2}\right]\end{array}$ \\
\hline
\end{tabular}

${ }^{(a)}$ DOC $=\left(\mathrm{CH}_{2} \mathrm{O}\right)_{x}\left(\mathrm{NH}_{3}\right)_{y}\left(\mathrm{H}_{3} \mathrm{PO}_{4}\right)_{z}$, where $x, y, \mathrm{z}$ represent the $\mathrm{C}: \mathrm{N}: \mathrm{P}$ ratios, set to 106:11:1 for coastal environments (Van Cappellen and Wang, 1995).

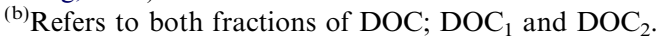

${ }^{\text {(c) }}$ Refers to the decomposition rate constants of $\mathrm{DOC}_{1}$ and $\mathrm{DOC}_{2}$, respectively.

${ }^{\text {(d) }} K_{\mathrm{d}}$, the dimensionless adsorption coefficient, is equal to $\mathrm{K}^{*} \mathrm{Fe}(\mathrm{OH})_{3}$.

and $\mathrm{Fe}(\mathrm{OH})_{3}$, are mobile species. The solid species are considered immobile and hence are only affected by local biogeochemical transformations. The concentration at the freshwater side is fixed for the solute species and set via trial and error to approximate the measured profiles at the first piezometer of the transect (PZ-10) (Figs. 1 and 2a). At the seawater side, seawater is allowed to enter the domain through advection. The boundary concentrations at the freshwater and seawater sides for each species are given in Table 1. The initial concentration of the solid species
( $\mathrm{Fe}(\mathrm{OH})_{3}$ and $\left.\mathrm{P}_{\mathrm{ads}}\right)$ is assumed to be zero throughout the entire model domain. Tables 2 and 3 show the rate formulations of the six transformation processes, including oxic DOC degradation, denitrification, $\mathrm{Fe}(\mathrm{OH})_{3}$ reduction, nitrification, $\mathrm{Fe}^{2+}$ oxidation and $\mathrm{PO}_{4}$ adsorption onto $\mathrm{Fe}(\mathrm{OH})_{3}$, and the list of reaction parameter values used in the simulations, respectively. The analysis of the major ions suggests conservative mixing of groundwater and seawater (Fig. 3). This implies that at this site, ion exchange processes for the major ions due to changes in the position of

Table 3

List of parameters used in the simulations

\begin{tabular}{|c|c|c|c|c|c|}
\hline Parameter (units) & Description & Value & Type $^{*}$ & Range in literature & Source \\
\hline$k_{\text {fox } 1}\left(\mathrm{~s}^{-1}\right)$ & $\begin{array}{l}\text { Rate constant for decomposition of } \\
\text { DOC }_{1}\end{array}$ & $3.0 \times 10^{-10}$ & $\mathrm{C}$ & & Canavan et al. (2006) \\
\hline$k_{\mathrm{fox} 2}\left(\mathrm{~s}^{-1}\right)$ & $\begin{array}{l}\text { Rate constant for decomposition of } \\
\mathrm{DOC}_{2}\end{array}$ & $3.0 \times 10^{-7}$ & M & $10^{-7}-10^{3}$ & Hunter et al. (1998) \\
\hline$k_{\text {nitri }}\left(\mathrm{mM}^{-1} \mathrm{~s}^{-1}\right)$ & Rate constant for nitrification & $4.8 \times 10^{-5}$ & M & $\begin{array}{l}1.6 \times 10^{-4}- \\
6.4 \times 10^{-4}\end{array}$ & Hunter et al. (1998) \\
\hline$k_{\text {feox }}\left(\mathrm{mM}^{-1} \mathrm{~s}^{-1}\right)$ & Rate constant for $\mathrm{Fe}^{2+}$ reoxidation & $8.8 \times 10^{-5}$ & M & $1.1 \times 10^{-5}-0.5$ & Canavan et al. (2006) \\
\hline $\mathrm{kmo} 2(\mathrm{mM})$ & Limiting concentration of $\mathrm{O}_{2}$ & 0.03 & $\mathrm{C}$ & $6.3 \times 10^{-4}-0.062$ & Hunter et al. (1998) \\
\hline kmno3 (mM) & Limiting concentration of $\mathrm{NO}_{3}^{-}$ & 0.001 & $\mathrm{C}$ & & $\begin{array}{l}\text { Van Cappellen and Wang } \\
\text { (1995) }\end{array}$ \\
\hline $\begin{array}{l}\mathrm{kmfe} \\
\left(\mathrm{mmol} \mathrm{dm}^{-3}\right)\end{array}$ & Limiting concentration of $\mathrm{Fe}(\mathrm{OH})_{3}$ & 18.95 & $\mathrm{C}$ & & $\begin{array}{l}\text { Van Cappellen and Wang } \\
\text { (1995) }\end{array}$ \\
\hline$K\left(\mathrm{dm}^{3} \mathrm{mmol}^{-1}\right)$ & Adsorption coefficient for $\mathrm{PO}_{4}$ & 100 & M & & \\
\hline
\end{tabular}

${ }^{*} \mathrm{C}$, constrained from literature; $\mathrm{M}$, model-derived parameter. 


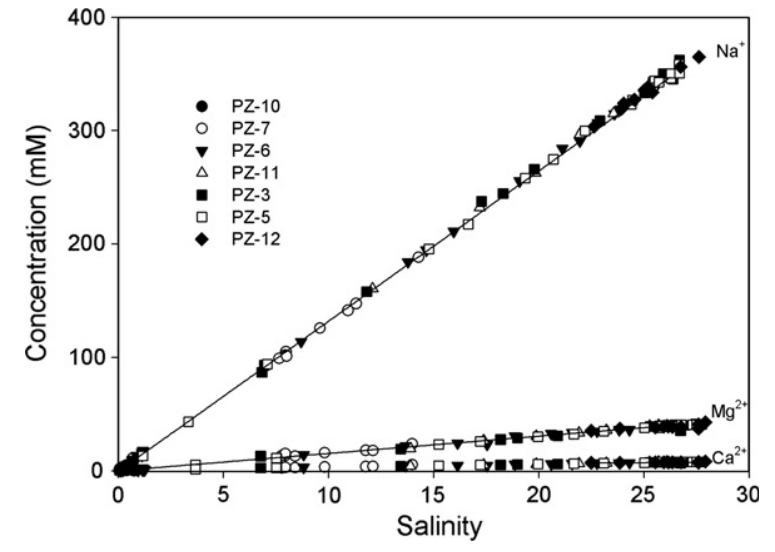

Fig. 3. Distribution of the major cation concentrations $\mathrm{Na}^{+}$, $\mathrm{Mg}^{2+}$ and $\mathrm{Ca}^{2+}$ ) versus salinity in all seven piezometers along the sampling transect. The solid lines indicate the conservative mixing lines between the freshwater and seawater endmembers for each cation.

the freshwater-seawater interface are not significant and hence, they are not included in the current reaction network. Similarly, the effect of potential $\mathrm{pH}$ variations on reaction rates is not explicitly accounted for. The modeled results presented here are for a total simulation time of $11 \mathrm{yr}$ and are at steady-state with respect to the solute species. All results refer to the sampling transect enclosed in the top right corner in Fig. 2a.

\section{RESULTS AND DISCUSSION}

\subsection{Field results}

Field data collected over the four consecutive sampling years (2002-2005) show similar general trends in the posi- tioning of the freshwater-seawater interface and the occurrence of the major plumes, as illustrated by the salinity, $\mathrm{NO}_{3}{ }^{-}, \mathrm{NH}_{4}{ }^{+}$and $\mathrm{PO}_{4}$ profiles in PZ-6 (Fig. 4a-d). Here, we do not present the entire field dataset but focus the model application on the June 2004 sampling campaign.

The 2D salinity distribution along the piezometer transect (Fig. 5a) shows a large salinity gradient, in which the porewater salinity increases from 0 to 28 over a vertical depth interval of $\sim 1.5 \mathrm{~m}$. This transition zone separates the upper freshwater lens that tapers towards the shore from a distinct lower saltwater wedge. Analysis of the porewater data for the other major chemical species, namely $\mathrm{NO}_{3}{ }^{-}, \mathrm{NH}_{4}{ }^{+}, \mathrm{PO}_{4}, \mathrm{Fe}^{2+}$ and DOC (Fig. 5b-f) shows that relatively high concentrations of $\mathrm{NH}_{4}^{+}$(Fig. 5c) and $\mathrm{PO}_{4}$ (Fig. 5d) co-occur in the saltwater wedge, with values falling within the range commonly found in coastal marine sediments (Lohse et al., 1995; Slomp et al., 1998). $\mathrm{NO}_{3}{ }^{-}$ is completely absent in the saltwater wedge (Fig. 5b).

In the freshwater part, two distinct "streamlines" with different geochemical composition are observed: an oxidizing, high- $\mathrm{NO}_{3}{ }^{-}$plume present at a depth of $\sim 4 \mathrm{~m}$ at PZ-10, which bends upwards over the saltwater wedge (Fig. 5b) and an upper freshwater "geochemical streamline", characterized by more reducing conditions containing high $\mathrm{NH}_{4}{ }^{+}$ (Fig. 5c), $\mathrm{PO}_{4}$ (Fig. 5d), $\mathrm{Fe}^{2+}$ (Fig. 5e) and DOC (Fig. 5f). The reduced freshwater plume reaches down to a depth of $3 \mathrm{~m}$ at PZ-10, becoming progressively narrower as the groundwater travels seaward. The $\mathrm{NH}_{4}^{+}$peak concentration increases from $\sim 0.05 \mathrm{mM}$ at PZ-10 to $\sim 0.15 \mathrm{mM}$ in PZ-6 and PZ-11, decreasing to $\sim 0 \mathrm{mM}$ between PZ-3 and PZ-5 (Fig. 5c). A gradual decrease in the peak $\mathrm{PO}_{4}$ (Fig. 5d) and DOC (Fig. 5f) concentration is observed from the most landward piezometer PZ-10 to the intertidal piezometer PZ-5. The fourfold increase in the peak $\mathrm{Fe}^{2+}$ concentration from $\sim 0.1 \mathrm{mM}$ at $\mathrm{PZ}-10$ to $\sim 0.4 \mathrm{mM}$ at $\mathrm{PZ}-7$ is followed by its near-complete disappearance in PZ-3 and

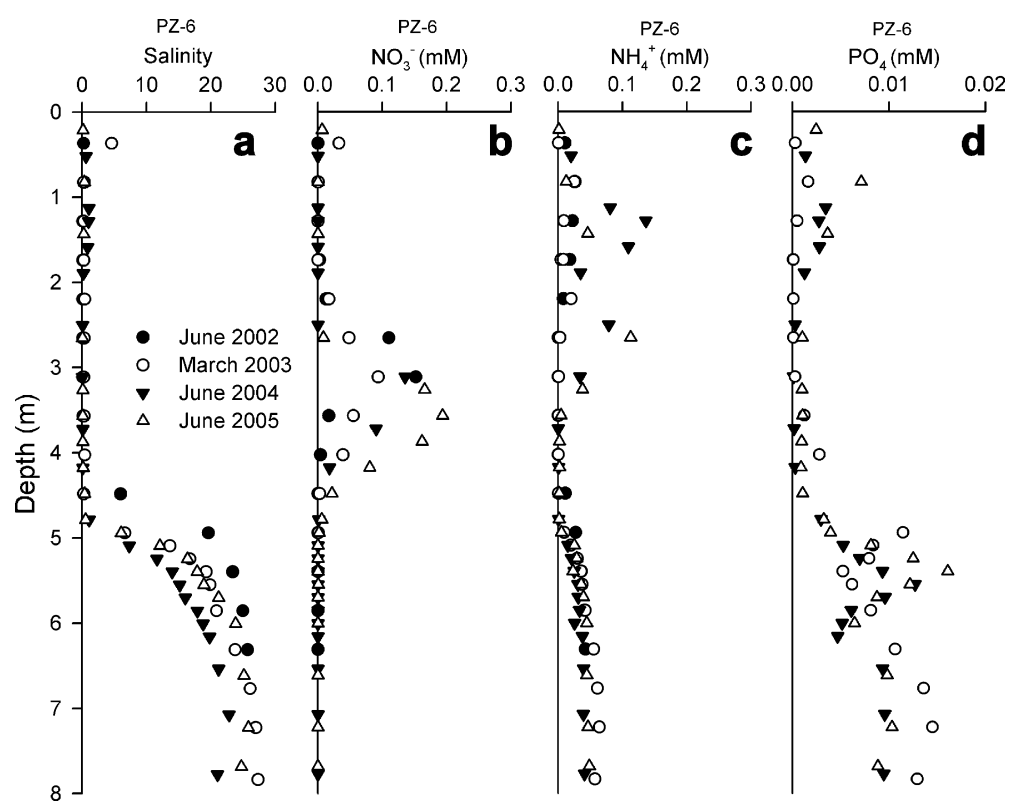

Fig. 4. Porewater measurements of (a) salinity, (b) $\mathrm{NO}_{3}{ }^{-}$, (c) $\mathrm{NH}_{4}{ }^{+}$and (d) $\mathrm{PO}_{4}$ for PZ-6 collected over four consecutive sampling campaigns (2002-2005). 

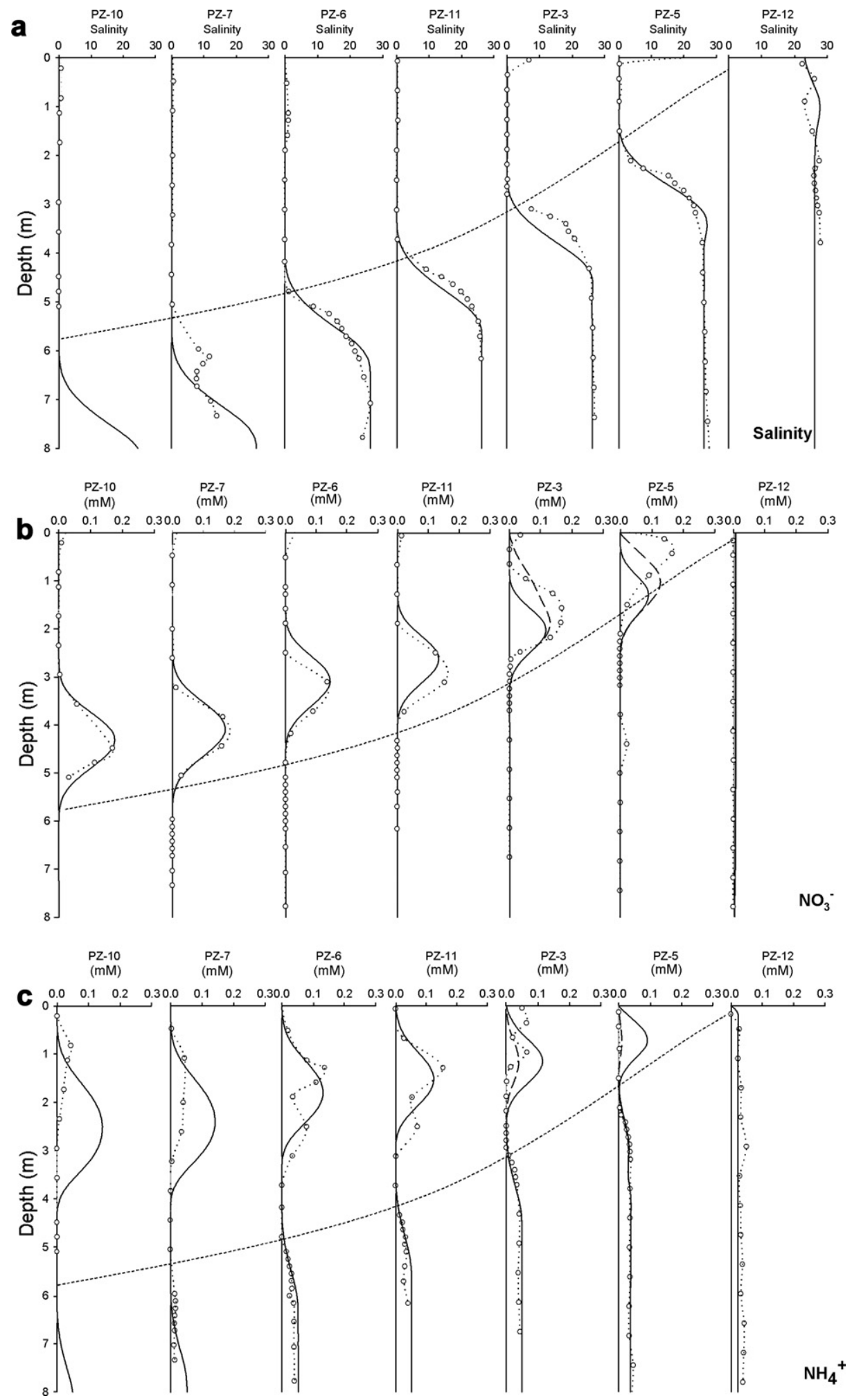

Fig. 5. Measured (dotted line with open circles) and modeled (solid line) depth profiles for (a) salinity, (b) $\mathrm{NO}_{3}^{-}$, (c) $\mathrm{NH}_{4}^{+}$, (d) $\mathrm{PO}_{4},(\mathrm{e}) \mathrm{Fe}^{2+}$ and (f) DOC $\left(\mathrm{DOC}_{1}+\mathrm{DOC}_{2}\right)$ in the $x-z$ plane along the beach transect. The dashed profiles in (b)-(e), PZ-3 and PZ-5, show the model fit obtained when the high- $\mathrm{O}_{2}$ zone in the surface intertidal sediments is not taken into account. All porewater measurements, except for DOC, were collected in June 2004. Porewater DOC values collected in June 2005 are used due to the higher quality and completeness of the dataset. The diagonal dotted line indicates the freshwater-seawater interface based on the salinity measurements. 

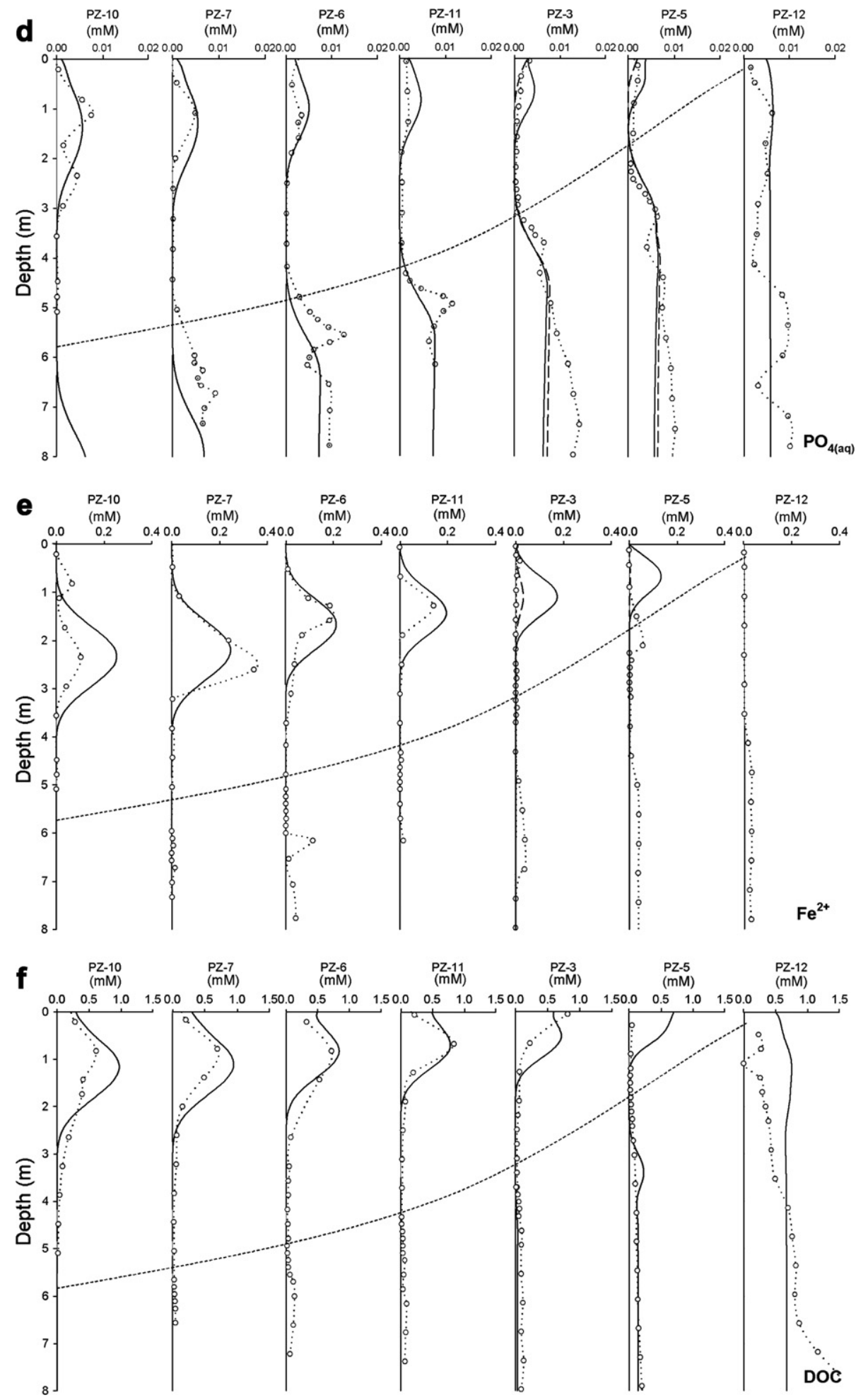

Fig. 5 (continued)

PZ-5, as the leading edge of the plume moves towards the shore.

The sources of $\mathrm{PO}_{4}, \mathrm{DOC}$ and $\mathrm{Fe}^{2+}$ in the freshwater are largely unknown, and several hypotheses exist on the occurrence of a reducing $\mathrm{NH}_{4}{ }^{+}$plume on top of a more oxidizing
$\mathrm{NO}_{3}{ }^{-}$plume. Spiteri et al. (2008) showed that such plumes can result from simultaneous nitrification and denitrification further inland within the aquifer. Kroeger and Charette (2008) speculate on the possible sources of the freshwater $\mathrm{NO}_{3}^{-}$and $\mathrm{NH}_{4}{ }^{+}$plumes, and suggest either (i) 


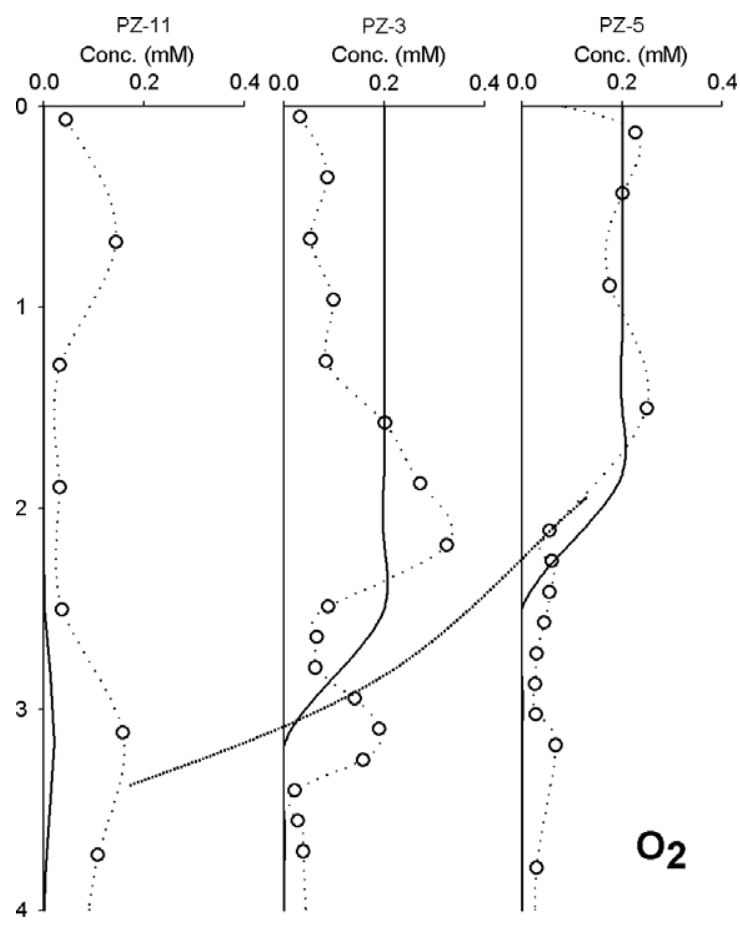

Fig. 6. Measured (dotted line with open circles) $\mathrm{O}_{2}$ concentration profiles PZ-11, PZ-3 and PZ-5 and imposed $\mathrm{O}_{2}$ concentrations (solid line) in the intertidal area. The diagonal line indicates the freshwater-seawater interface.

recharge from the inland Bog and Bourne ponds, or (ii) displacement of adsorbed nitrogen with seasalt in the freshwater part of the aquifer or (iii) a common nitrogen source for both plumes, developing into a reduced inner core and oxidized edge of the same plume.

As the freshwater lens gets thinner towards the beachface, the two freshwater "streamlines" converge, overlap and mix before discharging in the intertidal area between PZ-3 and PZ-5, a zone which is highly subject to high dispersive mixing due to the effect of waves and tides. This intertidal area at the head of the bay is characterized by a zone of iron oxide accumulation, referred to as the "iron curtain". Sediments in this zone (around PZ-3 and PZ-5) have a dark red, yellow and orange color down to a depth of at least $2 \mathrm{~m}$ and an iron content that is 10-15 times higher than elsewhere in the aquifer (Charette and Sholkovitz, 2002). Upward transport of $\mathrm{Fe}^{2+}$-rich saline pore water (Fig. 5e) could serve as a source of some of the precipitated $\mathrm{Fe}$ (Charette et al., 2005), although the freshwater plume is the ultimate source of "new" $\mathrm{Fe}^{2+}$ to the coastal sediments.

\subsection{Modeling results}

\subsubsection{Flow dynamics}

The modeled groundwater velocity at the landward freshwater side is $1.5 \times 10^{-6} \mathrm{~m} \mathrm{~s}^{-1}\left(13 \mathrm{~cm} \mathrm{~d}^{-1}\right)$, when a freshwater head of $0.24 \mathrm{~m}$ and a hydraulic gradient of $0.004 \mathrm{~m} \mathrm{~m}^{-1}$ is assumed (Fig. 2b). The latter corresponds to the upper limit of the range of hydraulic gradients measured in the valley area between high tide $\left(0.002 \mathrm{~m} \mathrm{~m}^{-1}\right)$ and low tide $\left(0.004 \mathrm{~m} \mathrm{~m}^{-1}\right)$ (Mulligan and Charette, 2006). The modeled landward velocity falls within the range of 9-43 $\mathrm{cm} \mathrm{d}^{-1}$ given in Mulligan and Charette (2006) for the low-lying region of the bay. It is also in good agreement with their average value of $15 \mathrm{~cm} \mathrm{~d}^{-1}$, calculated using Darcy's law, hydraulic gradient data and the geometric mean of the measured hydraulic conductivities. On approaching the coast, the groundwater flow rates increase up to $2.7 \times 10^{-5} \mathrm{~m} \mathrm{~s}^{-1}\left(235 \mathrm{~cm} \mathrm{~d}^{-1}\right)$ in the discharge zone due to the constriction of the freshwater in a smaller area (Fig. 2b). The model predicts the localized occurrence of SGD along the last $0.8 \mathrm{~m}$ of the top boundary, representing the seepage face on the beach parallel to the shoreline. SGD flows with an average rate of $1.4 \times 10^{-5} \mathrm{~m} \mathrm{~s}^{-1}\left(156 \mathrm{~cm} \mathrm{~d}^{-1}\right)$ and an average salinity of 5\% (ranging from $0.6 \%$ to $14 \%$ ). As suggested by Kroeger and Charette (2008), much of the fresh groundwater ultimately discharges as brackish water due to significant mixing with saline porewater in the shallow beach sediments prior to discharge. Unlike other SGD studies of Waquoit Bay using seepage meters (Michael et al., 2003; Sholkovitz et al., 2003), the predicted seepage face does not include offshore seepage areas but is restricted to the beachface, delimited by the position of the seaward piezometer PZ-12. In the saltwater wedge, the modeled flow velocity of the intruding seawater is as low as $2.4 \times 10^{-7} \mathrm{~m} \mathrm{~s}^{-1}\left(2 \mathrm{~cm} \mathrm{~d}^{-1}\right)$.

\subsubsection{Nitrogen dynamics}

The measured and modeled results for $\mathrm{NO}_{3}{ }^{-}$and $\mathrm{NH}_{4}{ }^{+}$ are shown in Fig. $5 \mathrm{~b}$ and c. In the landward section (from PZ-10 to PZ-11), the freshwater $\mathrm{NO}_{3}{ }^{-}$plume travels nearly conservatively (Fig. 5b), indicating that the conditions for effective denitrification are not met. In their analysis of the nutrient data collected in spring 2003 from the same sampling transect, Kroeger and Charette (2008) propose the occurrence of denitrification of the $\mathrm{NO}_{3}{ }^{-}$in the freshwater plume prior to its discharge, based on the substantial observed loss of $\mathrm{NO}_{3}{ }^{-}$around PZ-5. In our case, however, the peak $\mathrm{NO}_{3}{ }^{-}$concentration increases from PZ-11 to PZ3 , and stays rather elevated in intertidal piezometer PZ-5 where it is partially discharged. The model overestimates the $\mathrm{NH}_{4}{ }^{+}$concentrations and concurrently underestimates the $\mathrm{NO}_{3}{ }^{-}$concentrations at PZ-3 and PZ-5 (solid lines in Fig. $5 \mathrm{~b}$ and $\mathrm{c}$ ), as modeled nitrification rates are limited by the landward $\mathrm{O}_{2}$ supply. This points towards the need for an additional $\mathrm{O}_{2}$ source in the surface intertidal beach sediments. As reported by Ullman et al. (2003), tidal pumping and wave action may provide a constant source of $\mathrm{O}_{2}$ to sustain nitrification, as well as oxic degradation of the locally produced, labile organic matter higher on the beachface. In line with these observations, the $\mathrm{O}_{2}$ measurements in the surface intertidal sediments (PZ-3 and PZ-5) indicate higher concentrations, which do not originate from landward transport but are more likely supplied through aeration of the surface beachface sediments at low tide (Fig. 6). When an intertidal high- $\mathrm{O}_{2}$ zone is considered in the simulations (between $x=52.5$ and $x=58.5 \mathrm{~m}$ ) overlying the freshwater-seawater interface (Fig. 6), the model fits for $\mathrm{NO}_{3}{ }^{-}$and in particular $\mathrm{NH}_{4}{ }^{+}$are significantly improved (dashed lines in Fig. 5b and c) due to enhanced nitrification. 
The relative increase in the depth-integrated intertidal $\mathrm{NO}_{3}{ }^{-}$content due to nitrification is found to be $63 \%$ in PZ-3 and $73 \%$ in PZ-5 when an the additional $\mathrm{O}_{2}$ supply is considered. The corresponding model-derived, depthintegrated nitrification rates in PZ-3 and PZ-5 are $4 \times 10^{-7}$ and $1 \times 10^{-7} \mathrm{~mol} \mathrm{~m}^{-2} \mathrm{~s}^{-1}$, respectively. Our results indicate that a sharp redox front develops over a short distance in the intertidal area due to the efficient removal of the reactant $\left(\mathrm{NH}_{4}{ }^{+}\right)$as soon as it comes in contact with $\mathrm{O}_{2}$. The computed rates are higher than those reported for freshwater lake sediments $\left(7 \times 10^{-9} \mathrm{~mol} \mathrm{~N} \mathrm{~m}^{-2} \mathrm{~s}^{-1}\right.$; Canavan et al., 2006) and shallow coastal marine sediments $\left(3.6 \times 10^{-9} \mathrm{~mol} \mathrm{~N} \mathrm{~m}^{-2} \mathrm{~s}^{-1}\right.$; Wang and Van Cappellen, 1996).

\subsubsection{Phosphorus and iron dynamics}

Analogous to the oxidation of $\mathrm{NH}_{4}{ }^{+}$to $\mathrm{NO}_{3}{ }^{-}$through nitrification, the oxidation of $\mathrm{Fe}^{2+}$ and disappearance of the $\mathrm{Fe}^{2+}$ plume in the intertidal area (Fig. 5e) is obtained when accounting for $\mathrm{O}_{2}$ infiltration (Fig. 5a; dashed lines). Model results for the $\mathrm{O}_{2}$ infiltration scenario closely match the observed simultaneous precipitation of $\mathrm{Fe}(\mathrm{OH})_{3}$ as an "iron curtain" (not shown) and the subsequent removal of freshwater $\mathrm{PO}_{4}$ through adsorption (Fig. 5d) in the intertidal area. The mitigation of the $\mathrm{Fe}^{2+}$ plume is more likely attributed to $\mathrm{Fe}^{2+}$ oxidation with $\mathrm{O}_{2}$ rather than to autotrophic denitrification with $\mathrm{Fe}^{2+}$, since $\mathrm{NO}_{3}{ }^{-}$concentrations increase between PZ-3 and PZ-5 (Fig. 5b). Changes in $\mathrm{pH}$ along the freshwater-seawater continuum may also play a role in enhancing $\mathrm{Fe}^{2+}$ oxidation (Spiteri et al., 2006). The simulation time required to precipitate $103 \mathrm{mmol} \mathrm{dm}^{-3} \mathrm{Fe}(\mathrm{OH})_{3}$ in the intertidal area, corresponding to the $\sim 3000 \mathrm{ppm} \mathrm{Fe}$ measured in the intertidal sediment cores taken from the head of Waquoit Bay (Charette et al., 2005), is $11 \mathrm{yr}$. During the same time period, the model predicts the formation of a maximum of $3.9 \times 10^{-3} \mathrm{~mol} \mathrm{dm}{ }^{-3}$ or $60 \mathrm{ppm} \mathrm{PO}_{4(\mathrm{ads})}$, which falls within the range of $25-200 \mathrm{ppm} \mathrm{P}$ found in the same sediment cores. The thin $\mathrm{PO}_{4}$ plume observed along the freshwater-seawater interface may be associated either with the mobilization of iron oxides (Charette et al., 2005), or with changes in porewater $\mathrm{pH}$ with salinity along the interface, which are not resolved with the current model formulation.

Depth-integrated rates of $\mathrm{Fe}^{2+}$ oxidation in PZ-3 and PZ-5 $\left(5 \times 10^{-7}\right.$ and $4.8 \times 10^{-8} \mathrm{~mol} \mathrm{~m}^{-2} \mathrm{~s}^{-1}$, respectively) are higher than those reported by Canavan et al. (2006) for freshwater lake sediments $\left(3.5 \times 10^{-9} \mathrm{~mol} \mathrm{Fe} \mathrm{m}^{-2} \mathrm{~s}^{-1}\right)$ and Wang and Van Cappellen (1996) for shallow coastal marine sediments $\left(3.5 \times 10^{-9} \mathrm{~mol} \mathrm{Fe} \mathrm{m}^{-2} \mathrm{~s}^{-1}\right)$. The higher process rates in the coastal sediments of Waquoit Bay, despite the relatively lower values for rate constants used here (see Table 3), could be the result of the predominantly advective transport, which supplies a higher input $\mathrm{Fe}^{2+}$ (and $\mathrm{NH}_{4}^{+}$) than normally observed in typical freshwater or marine sediments.

\subsubsection{DOC dynamics}

Model results suggest that the terrestrial DOC $\left(\mathrm{DOC}_{1}\right)$ that reaches the coast is rather refractory, with a degradation rate constant of $3.0 \times 10^{-10} \mathrm{~s}^{-1}\left(0.01 \mathrm{yr}^{-1}\right)$ (Fig. 5f).
The model, however, overestimates the concentrations of the terrestrial refractory DOC in the intertidal area. The simulation also reveals that the relatively high $\mathrm{NH}_{4}{ }^{+}$porewater concentrations in the saltwater wedge might be produced from the remineralization of labile organic carbon in saline estuarine sediments $\left(\mathrm{DOC}_{2}\right)$ (Kroeger and Charette, 2008), followed by dilution due to the landward advecting seawater. If a degradation rate constant of $3.0 \times 10^{-7} \mathrm{~s}^{-1}\left(10 \mathrm{yr}^{-1}\right)$ is used (Fig. 5c, d and $\mathrm{f}$ ), the model is able to reproduce the drop in $\mathrm{DOC}_{2}$ from $\sim 0.7 \mathrm{mM}$ at PZ-12 to $0.1 \mathrm{mM}$ at PZ-5. At the same time, a satisfactory model fit is obtained for both $\mathrm{NH}_{4}^{+}$and $\mathrm{PO}_{4}$ saltwater profiles, pointing towards a common origin. This seaward source of reactive DOC possibly originates from the leaching of organic matter deposits, derived from the brown and green algal blooms that cover the bay, beach and intertidal area in late spring and summer (Charette et al., 2005).

\subsection{SGD of nutrients}

A budget of $\mathrm{NO}_{3}^{-}, \mathrm{NH}_{4}{ }^{+}$and $\mathrm{PO}_{4}$ for the entire coastal aquifer of Waquoit Bay is shown in Fig. 7. A comparison of the computed fluxes of nutrients through SGD (Fig. 7a, c and e) clearly shows that $\mathrm{NO}_{3}{ }^{-}$is the major nutrient source to the bay, with fluxes being 16 and 80 times higher than those of $\mathrm{NH}_{4}^{+}$and $\mathrm{PO}_{4}$, respectively. The ratio of the influx of $\mathrm{NO}_{3}{ }^{-}$through freshwater and seawater (Fig. 7a) indicates that the source of $\mathrm{NO}_{3}{ }^{-}$in SGD is predominantly freshwater. Most of the freshwater $\mathrm{NH}_{4}{ }^{+}$input is removed by nitrification prior to discharge, which is by far the most prominent nutrient transformation process (Fig. 7d). In fact, the contribution of nitrification to SGD of $\mathrm{NO}_{3}^{-}$exceeds the groundwater input of $\mathrm{NO}_{3}{ }^{-}$from terrestrial sources (Fig. 7a and b). Therefore, the $\mathrm{NH}_{4}{ }^{+}$present in SGD is presumably the result of DOC degradation in the saltwater wedge, which is recycled out back to the coastal waters through recirculated seawater. This remineralized $\mathrm{NH}_{4}{ }^{+}$flux becomes even more significant when offshore seepage areas are considered (Kroeger and Charette, 2008). Seawater contributes to approximately one third of the $\mathrm{PO}_{4}$ influx into the subterranean estuary, since a major fraction of the freshwater $\mathrm{PO}_{4}$ is sorbed as the groundwater flows through the "iron curtain" (Fig. 7f). As a result of the limited removal of $\mathrm{NO}_{3}{ }^{-}$through denitrification (Fig. 7b), in combination with the efficient removal of $\mathrm{PO}_{4}$ (Fig. 7f), the ratio of the average dissolved inorganic nitrogen $\left(\mathrm{NO}_{3}{ }^{-}+\mathrm{NH}_{4}{ }^{+}\right)$ and inorganic $\mathrm{PO}_{4}$ concentrations (DIN: $\mathrm{PO}_{4}$ ratio) in the SGD is found to be 50 . Note that DOP and DON can also be quantitatively important in groundwater and can affect ratios of total N:total $\mathrm{P}$ in SGD (Burnett et al., 2007).

Table 4 shows the nutrient discharge rates extrapolated over the entire length of the shoreline along the valley (210 m; Mulligan and Charette, 2006), as well as the normalized fluxes per unit seepage area, assuming a beachface seepage width of $0.8 \mathrm{~m}$. Up to $95 \%$ of the total DIN flux $\left(2.9 \times 10^{-4} \mathrm{~mol} \mathrm{~s}^{-1}\right)$ is in the form of $\mathrm{NO}_{3}{ }^{-}$. There is a significant discrepancy between the estimate of DIN flux de- 

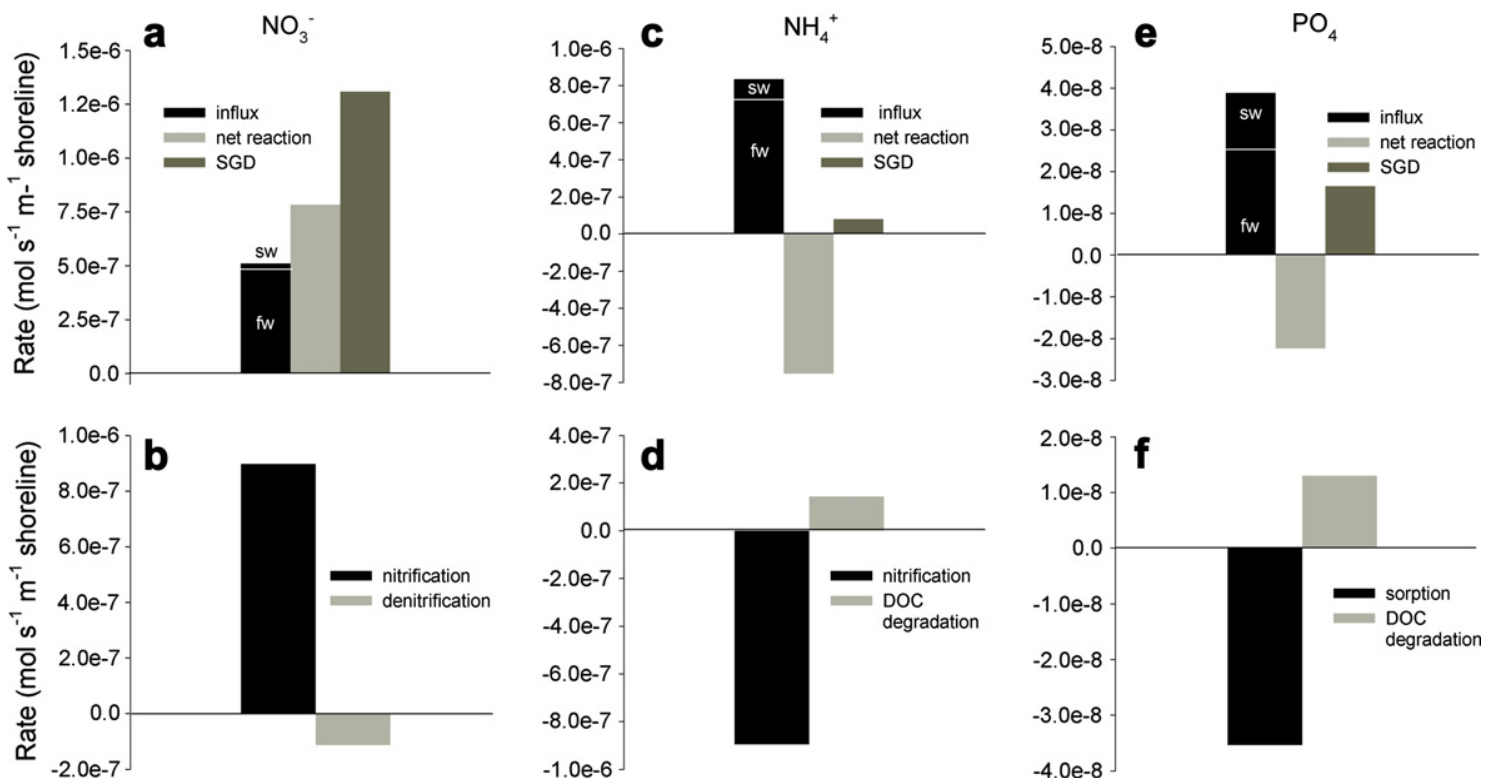

Fig. 7. Calculated influx rates (fw, freshwater; sw, seawater), net transformation rates due to reaction and efflux rates through SGD for (a) $\mathrm{NO}_{3}^{-}$, (c) $\mathrm{NH}_{4}^{+}$and (e) $\mathrm{PO}_{4}$ in $\mathrm{mol} \mathrm{s}^{-1} \mathrm{~m}^{-1}$ shoreline. (b, $\mathrm{d}$ and f) The rates of the biogeochemical reactions which add up to the net transformation rates for $\mathrm{NO}_{3}^{-}, \mathrm{NH}_{4}^{+}$and $\mathrm{PO}_{4}$, respectively.

Table 4

Nitrogen and phosphorus fluxes through SGD

\begin{tabular}{lll}
\hline & \multicolumn{2}{l}{ Nutrient fluxes } \\
\cline { 2 - 3 } & $\mathrm{mol} \mathrm{s}^{-1^{*}}$ & $\mu \mathrm{mol} \mathrm{m}{ }^{-2} \mathrm{~d}^{-1^{* *}}$ \\
\hline $\mathrm{DIN}$ & $2.9 \times 10^{-4}$ & $1.5 \times 10^{5}$ \\
$\mathrm{NO}_{3}{ }^{-}$ & $2.7 \times 10^{-4}$ & $1.4 \times 10^{5}$ \\
$\mathrm{NH}_{4}{ }^{+}$ & $1.7 \times 10^{-5}$ & $8.7 \times 10^{3}$ \\
$\mathrm{PO}_{4}$ & $3.4 \times 10^{-6}$ & $1.8 \times 10^{3}$ \\
\hline
\end{tabular}

* Assuming a shoreline length along the valley of $210 \mathrm{~m}$.

** Assuming a seepage face of $0.8 \mathrm{~m}$.

rived from this study and that given in Charette et al. (2001) $\left(2.4 \times 10^{-2} \mathrm{~mol} \mathrm{~s}^{-1}\right)$ for the same bay. In Charette et al. (2001), the calculation of the flux is based on a DIN concentration in the groundwater along the shoreline of $0.058 \mathrm{mM}$, which is very close to our average DIN concentration in $\mathrm{SGD}(0.057 \mathrm{mM})$, and a radium-derived volumetric SGD rate of $0.43 \mathrm{~m}^{3} \mathrm{~s}^{-1}$ (most of which is saline). However, the SGD rate was calculated over the total surface area of the bay $\left(39 \times 10^{5} \mathrm{~m}^{2}\right)$, which is much larger than the seepage face considered in this study $\left(168 \mathrm{~m}^{2}\right.$; $0.8 \mathrm{~m} \times 210 \mathrm{~m}$ ). Therefore, when the DIN loading is expressed in moles per unit time per unit area, the estimate of Charette et al. (2001) for the whole bay is in fact much lower $\left(\sim 500 \mu \mathrm{mol} \mathrm{m}{ }^{-2} \mathrm{~d}^{-1}\right)$ than the one obtained in this study $\left(1.5 \times 10^{5} \mu \mathrm{mol} \mathrm{m} \mathrm{m}^{-2} \mathrm{~d}^{-1}\right.$; Table 4$)$.

\subsection{Scenarios}

In this section, we assess the effect of specific parameters that might alter the present-day biogeochemical dynamics in the subterranean estuary of Waquoit Bay. In particular, the response of the model to a change in the reactivity of terrestrial DOC, an increase in landward $\mathrm{PO}_{4}$ source concentration and a change in the flow regime is investigated.

\subsubsection{Increased reactivity of terrestrial DOC}

We assess the effect of a hypothetical discharge of a highly reactive $\mathrm{DOC}_{1}\left(\mathrm{kf}_{\mathrm{ox} 1}=0.1 \mathrm{yr}^{-1}\right)$, which could originate from the natural seepage of the eutrophied ponds located upstream in the head of bay. Model simulations show that despite the increase in organic carbon reactivity compared to the baseline simulation, denitrification remains marginal (not shown). This is because $\mathrm{NO}_{3}{ }^{-}$removal is predominantly limited by the lack of spatial overlap between the DOC and $\mathrm{NO}_{3}{ }^{-}$plumes. Upon convergence of the two plumes within the intertidal area, denitrification is still inhibited by the presence of $\mathrm{O}_{2}$ in the surface sediments. Conversely, nitrification of the $\mathrm{NH}_{4}{ }^{+}$produced from the degradation of the reactive $\mathrm{DOC}_{1}$ fraction causes the $\mathrm{NO}_{3}{ }^{-}$concentration in PZ-3 and PZ-5 to increase by up to $20 \%$ (not shown). Therefore, given the present flow conditions in Waquoit Bay, $\mathrm{NO}_{3}{ }^{-}$removal does not appear to be limited by organic carbon reactivity.

\subsubsection{Efficiency of the "iron curtain"}

The capacity of the "iron curtain" to attenuate $\mathrm{PO}_{4}$ concentrations is tested by comparing the SGD of $\mathrm{PO}_{4}$ with (Section 5.2.2) and without the presence of the "iron curtain" in the intertidal area. The flow field is identical in both cases and is used to simulate the propagation of a freshwater source contaminated with $\mathrm{PO}_{4}$. The selected concentration $(0.18 \mathrm{mM})$ falls within the range observed in groundwater systems affected by waste-water discharge (e.g., Wilhelm et al., 1994; Robertson, 1995). The breakthrough curve obtained for the scenario without "iron curtain" shows a sharp increase in SGD of $\mathrm{PO}_{4}$ roughly 100 days after the start of 
infiltration (Fig. 8). In the presence of an "iron curtain" in the intertidal zone, the increase in $\mathrm{PO}_{4}$ concentration in the SGD is significantly slower and more gradual. In this case, the predicted $\mathrm{PO}_{4}$ concentration after 1000 days is still as low as $0.005 \mathrm{mM}$, with a retardation factor of $10^{4}$. Therefore, considering that $\mathrm{PO}_{4}$ concentrations on the order of $0.001 \mathrm{mM}(\sim 0.03 \mathrm{mg} / \mathrm{L})$ are sufficient to stimulate algal growth in aquatic environments (Dillon and Rigler, 1974; Schindler, 1977), Fe oxide accumulations in coastal aquifers can act as important geochemical barriers and could help prevent coastal eutrophication.

\subsubsection{Effect of sealevel rise}

A global-scale sealevel rise of $40-65 \mathrm{~cm}$ is predicted by the year 2100 (Gornitz, 1995). Here, we simulate the effect of a $50 \mathrm{~cm}$ increase in sealevel on the biogeochemistry of

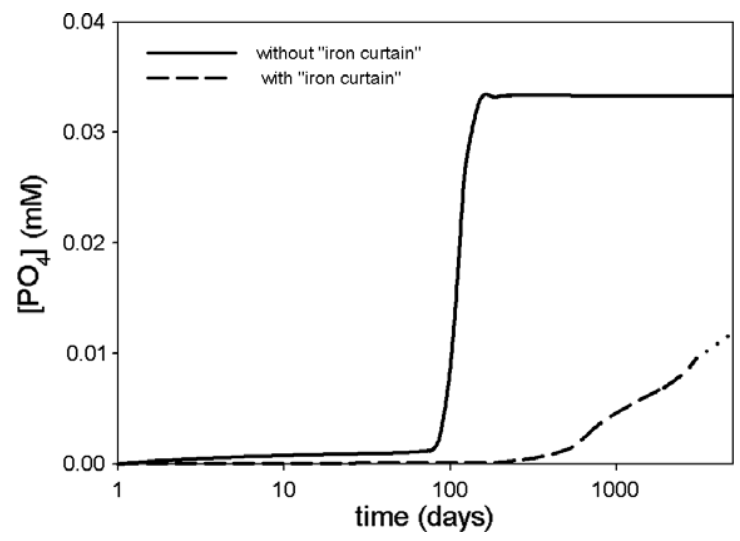

Fig. 8. Breakthrough curves for $\mathrm{PO}_{4}$ concentration in $\mathrm{SGD}$ in the (i) absence and (ii) presence of an "iron curtain". Note that the latter scenario assumes no feedback of the formation of the "iron curtain" on the flow pattern. the subterranean estuary in Waquoit Bay. In this case, taking into account the average slope of the land surface, the seawater infiltration along the beachface could be extended significantly and occur over a distance of at least $4 \mathrm{~m}$ (between $x=56$ and $x=60 \mathrm{~m}$ ). The simulation reveals an upward shift in the freshwater-seawater interface by roughly $1 \mathrm{~m}$ as a result of the sealevel rise. This leads to a constriction of the freshwater part of the aquifer and a landward movement of the zone of seepage. Yet, the model predicts only a marginal increase in the overlap of the redox plumes. Assuming that the $\mathrm{O}_{2}$ penetration is limited by the freshwater-seawater interface (Fig. 6), the upward shift in the saline front results in a decrease in the nitrification rate (Fig. $9 \mathrm{~b}$ and $\mathrm{d}$ ), which is no longer the main contributor of $\mathrm{NO}_{3}^{-}$to SGD (Fig. 9a). Production of $\mathrm{NH}_{4}^{+}$and $\mathrm{PO}_{4}$ from $\mathrm{DOC}_{2}$ degradation (Fig. 9d and f) becomes also slightly more important, due to the increased influx of labile marine $\mathrm{DOC}_{2}$. Yet, overall, the SGD of DIN and $\mathrm{PO}_{4}$ at this site is relatively insensitive to variations in the sealevel.

\section{CONCLUSIONS}

A reactive transport model is used to characterize the biogeochemical dynamics in the subterranean estuary of Waquoit Bay (Fig. 10). Results reveal the presence of three distinct zones within the coastal aquifer. In the landward part (PZ-10 to PZ-11), redox transformations are limited by the lack of spatial overlap between the two freshwater "geochemical streamlines" and result in nearly conservative transport of the solute species. In particular, the model predicts marginal $\mathrm{NO}_{3}{ }^{-}$removal through denitrification, even if the reactivity of the terrestrial DOC is increased by one order of magnitude. As the groundwater travels seaward, the redox plumes start converging until they overlap completely and
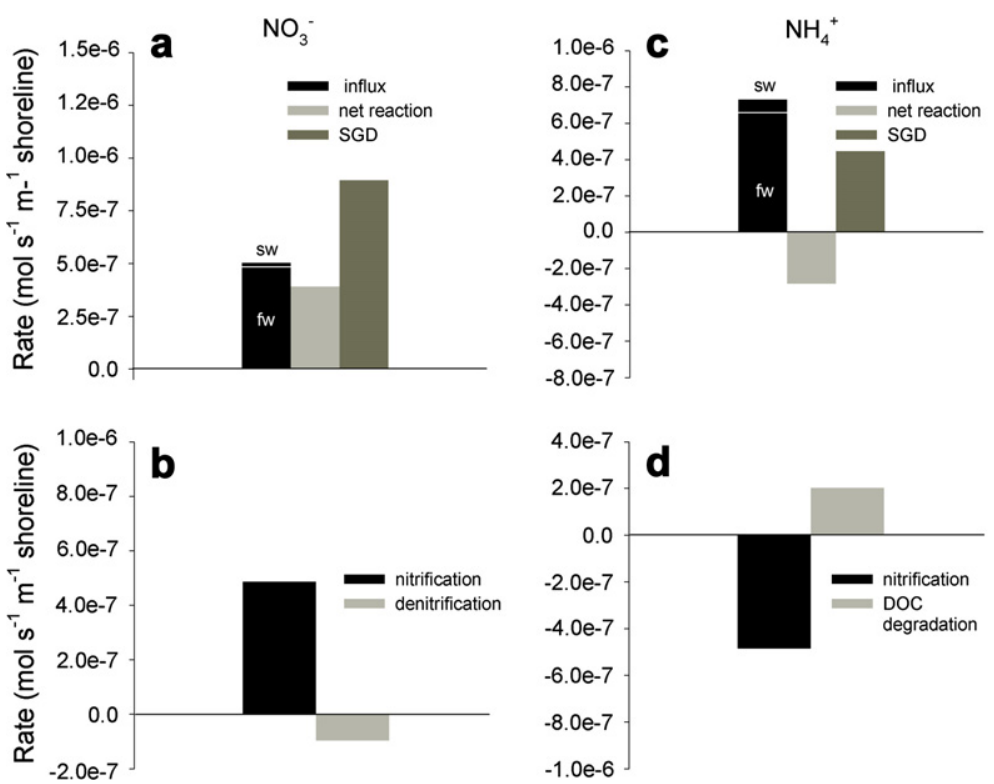

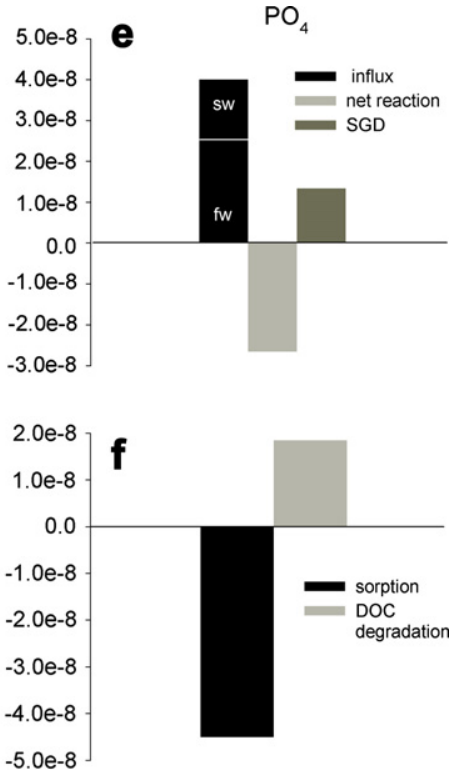

$-5.0 e-8$

Fig. 9. Calculated influx rates ( $\mathrm{fw}$, freshwater; sw, seawater), net transformation rates due to reaction and efflux rates through SGD for (a) $\mathrm{NO}_{3}^{-}$, (c) $\mathrm{NH}_{4}^{+}$and (e) $\mathrm{PO}_{4}$ in $\mathrm{mol} \mathrm{s}^{-1}$ obtained when a hypothetical $50 \mathrm{~cm}$ sealevel rise is assumed. (b, $\mathrm{d}$ and $\mathrm{f}$ ) The rates of the biogeochemical reactions which add up to the net transformation rates for $\mathrm{NO}_{3}{ }^{-}, \mathrm{NH}_{4}{ }^{+}$and $\mathrm{PO}_{4}$, respectively. 


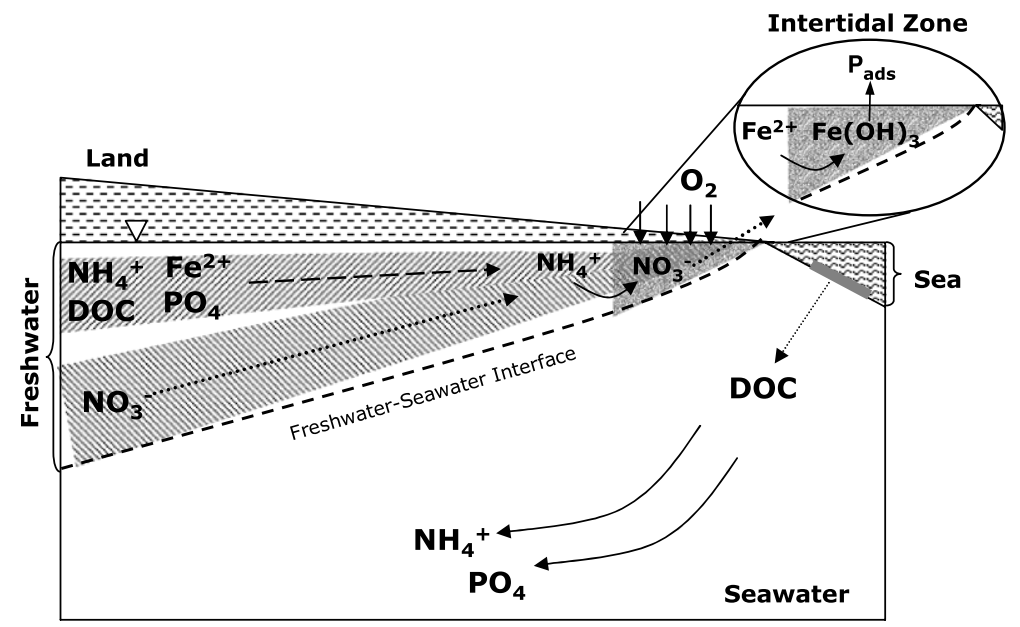

Fig. 10. Schematic representation of the nutrient distributions and biogeochemical transformations in the subterranean estuary of Waquoit Bay.

mix dispersively in the highly reactive intertidal area. Despite the high advective groundwater flow rates prior to seepage, the continuous supply of $\mathrm{O}_{2}$ from the beachface sustains elevated nitrification and $\mathrm{Fe}^{2+}$ oxidation rates, which are found to be at least one order of magnitude higher than the corresponding oxidation rates in fresh water lakes and shallow coastal marine sediments. Iron oxidation leads to the formation of an "iron curtain" onto which $\mathrm{PO}_{4}$ effectively sorbs. This narrow and dynamic mixing zone is currently poorly resolved and warrants further experimental studies. In the saltwater wedge, the degradation of the labile marine-derived DOC is a dominant process and results in elevated $\mathrm{NH}_{4}^{+}$ and $\mathrm{PO}_{4}$ porewater concentrations. While $\mathrm{NO}_{3}{ }^{-}$concentrations in SGD reflect those of the freshwater source, the concentrations of $\mathrm{PO}_{4}$ in SGD are significantly reduced due to the adsorption on the iron oxide-rich barrier near the beachface. As a result, the DIN:PO $\mathrm{PO}_{4}$ ratio of SGD is close to 50 .

\section{ACKNOWLEDGMENTS}

This research was funded by the Netherlands Organisation for Scientific Research (NWO) and WHOI Guest Student Program (C. Spiteri), the Royal Netherlands Academy of Arts and Sciences (KNAW) and the Netherlands Organization for Scientific Research (NWO VIDI-grant) (C.P. Slomp), the US National Science Foundation NSF-OCE0095384 and NSF-OCE0425061 (M.A. Charette) and the Georgia Sea Grant of the National Sea Grant College Program of the U.S. Department of Commerce's National Oceanic and Atmospheric Administration under NOAA Grant \#NA04OAR4170033 (C. Meile). The views herein do not necessarily reflect the views of any of those organizations. C. Spiteri thanks Ann Mulligan for her help and suggestions during her visit to WHOI. Special thanks go to Pierre Regnier who provided valuable comments and advice which greatly facilitated the completion of this study.

\section{REFERENCES}

Beck A. J., Tsukamoto Y., Tovar-Sanchez A., Huerta-Diaz M., Bokuniewicz H. J. and Sañudo-Wilhelmy S. A. (2007) Importance of geochemical transformations in determining submarine groundwater discharge-derived trace metal and nutrient fluxes. Appl. Geochem. 22, 477-490.

Breier J. A., Breier C. F. and Edmonds H. N. (2005) Detecting submarine groundwater discharge with synoptic surveys of sediment resistivity, radium, and salinity. Geophys. Res. Lett. 32. doi:10.1029/2005GL024639.

Burnett W. C., Aggarwal P. K., Aureli A., Bokuniewicz H., Cable J. E., Charette M. A., Kontar E., Krupa S., Kulkarni K. M., Loveless A., Moore W. S., Oberdorfer J. A., Oliveira J., Ozyurt N., Povinec P., Privitera A. M. G., Rajar R., Ramessur R. T., Scholten J., Stieglitz T., Taniguchi M. and Turner J. V. (2006) Quantifying submarine groundwater discharge in the coastal zone via multiple methods. Sci. Total Environ. 367, 498-593.

Burnett W. C., Wattayakorn G., Taniguchi M., Dulaiova H., Sojisuporn P., Rungsupa S. and Ishitobi T. (2007) Groundwater-derived nutrient inputs to the Upper Gulf of Thailand. Cont. Shelf Res. 27, 176-190.

Cambareri T. C. and Eichner E. M. (1998) Watershed delineation and groundwater discharge to a coastal embayment. Groundwater 36, 626-634.

Canavan R. W., Slomp C. P., Jourabchi P., Van Cappellen P., Lavermann A. M. and Van den Berg G. A. (2006) Organic matter mineralization in sediment of a coastal freshwater lake and response to salinization. Geochim. Cosmochim. Acta 70, 2836-2855.

Capone D. G. and Slater J. M. (1990) Interannual patterns of water-table height and groundwater derived nitrate in nearshore sediments. Biogeochemistry 10, 277-288.

Charette M. A. and Sholkovitz E. R. (2002) Oxidative precipitation of groundwater-derived ferrous iron in the subterranean estuary of a coastal bay. Geophys. Res. Lett. 29, article no. 1444.

Charette M. A., Buesseler K. O. and Andrews J. E. (2001) Utility of radium isotopes for evaluating the input and transport of groundwater-derived nitrogen to a Cape Cod estuary. Limnol. Oceanogr. 46, 465-470.

Charette M. A., Sholkovitz E. R. and Hansel C. M. (2005) Trace element cycling in a subterranean estuary: Part 1. Geochemistry of the permeable sediments. Geochim. Cosmochim. Acta 69, 2095-2109.

Charette M. A. and Allen M. C. (2006) Precision ground water sampling in coastal aquifers using a direct-push, shielded-screen well-point system. Ground Water Monit. Remediation 26, 87-93.

Corbett D. R., Kump L., Dillon K., Burnett W. and Chanton J. (2000) Fate of wastewater-borne nutrients under low discharge 
conditions in the subsurface of the Florida Keys, USA. Mar. Chem. 69(1-2), 99-115.

Davison W. and Seed G. (1983) The kinetics of oxidation of ferrous iron in synthetic and natural waters. Geochim. Cosmochim. Acta 47, 67-79.

DeSimone L. A. and Howes B. L. (1996) Denitrification and nitrogen transport in a coastal aquifer receiving wastewater discharge. Environ. Sci. Technol. 30, 1152-1162.

Dillon P. J. and Rigler F. H. (1974) The phosphorus-chlorophyll relationship in lakes. Limnol. Oceanogr. 19, 767-773.

Giblin A. E. and Gaines A. G. (1990) Nitrogen inputs to a marine embayment: the importance of groundwater. Biogeochemistry 10, 309-328.

Gornitz V. (1995) A comparison of differences between recent and late Holocene sea-level trends from eastern North America and other selected regions. J. Coastal Res. 17, 287-297.

Hunter K. S., Wang Y. and Van Cappellen P. (1998) Kinetic modeling of microbially driven redox chemistry of subsurface environments: coupling transport, microbial metabolism and geochemistry. J. Hydrol. 209, 53-80.

Hwang D. W., Kim G., Lee Y.-W. and Yang H.-S. (2005) Estimating submarine inputs of groundwater and nutrients to a coastal bay using radium isotopes. Mar. Chem. 96, 6171.

Krest J. M., Moore W. S., Gardner L. R. and Morris J. T. (2000) Marsh nutrient export supported by groundwater discharge evidence from radium isotope measurements. Global Biogeochem. Cycles 14, 167-176.

Kroeger K. D. and Charette M. A. (2008) Nitrogen biogeochemistry of submarine groundwater discharge. Limnol. Oceanogr. 53, 1025-1039.

LeBlanc D. R., Guswa J. H., Frimpter M. H. and Londquist C. J. (1986) Groundwater resources of Cape Cod, Massachusetts. U.S. Geological Survey Hydrologic Investigations Atlas HA692, 4 plates.

Lohse L., Malschaert J. F. P., Slomp C. P., Helder W. and van Raaphorst W. (1995) Sediment-water fluxes of inorganic nitrogen compounds along the transport route of organic matter in the North Sea. Ophelia 41, 173-197.

Masterson J. P., Walter D. A. and Savoie J. (1997) Use of particle tracking to improve numerical model calibration and to analyze ground-water flow and contaminant migration. Massachusetts Military Reservation, western Cape Cod Massachusetts. U.S. Geological Survey Water-Supply Paper 2482, p. 50.

Masterson J. P. and Walter D. A. (2000) Delineation of groundwater recharge areas, Western Cape Cod, Massachusetts. Water-Resources Investigation Report 00-4000. Reston, VA. U.S. Department of Interior Geological Survey.

Michael H. A., Lubetsky J. and Harvey C. F. (2003) Characterizing submarine groundwater discharge: a seepage meter study in Wauoit Bay, Massachusetts. Res. Lett. 30. doi:10.1029/ 2002 GL016000.

Michael H. A. (2004) Seasonal dynamics in coastal aquifers: investigation of submarine groundwater discharge through field measurements and numerical models, Ph.D. Thesis, Massachusetts Institute of Technology.

Michael H. A., Mulligan A. E. and Harvey C. F. (2005) Seasonal oscillations in water exchange between aquifers and the coastal ocean. Nature 25, 1145-1148.

Moore W. S. (1999) The subterranean estuary: a reaction zone of groundwater and sea water. Mar. Chem. 65, 111-125.

Moore W. S. (2006) Radium isotopes as tracers of submarine groundwater discharge in Sicily. Cont. Shelf Res. 26, 852-861.

Mulligan A. E. and Charette M. A. (2006) Intercomparison of submarine groundwater discharge estimates from a sandy unconfined aquifer. J. Hydrol. 327, 411-425.
Nowicki B. L., Requintina E., van Keuren D. and Portnoy J. (1999) The role of sediment denitrification in reducing groundwater-derived nitrate inputs to Nauset Marsh Estuary, Cape Cod, Massachusetts. Estuaries 22, 245-259.

Oldale R. N. (1976) Notes on the generalized geologic map of Cape Cod. U.S. Geological Survey Open File Report, pp. 122-127.

Oldale R. N. (1981) Pleistocene stratigraphy of Nantucket, Martha's Vineyard, the Elizabeth Islands, and Cape Cod, Massachusetts. In Late Wisconsinan Glaciation of New England (eds. G. J. Larson and B. D. Stone). Kenall/Hunt, Dubuque, Iowa.

Robertson W. D. (1995) Development of steady-state phosphate concentrations in septic system plumes. J. Contam. Hydrol. 19, 289-305.

Robinson C., Li L. and Barry D. A. (2007) Effect of tidal forcing on a subterranean estuary. Adv. Water Resour. 30, 851-865. doi:10.1016/j.advwatres.2006.07.006.

Schindler D. W. (1977) Evolution of phosphorus limitation in lakes. Science 195, 260-262.

Shellenbarger G. G., Monismith S. G., Genin A. and Paytan A. (2006) The importance of submarine groundwater discharge to the nearshore nutrient supply in the Gulf of Aqaba (Israel). Limnol. Oceanogr. 51, 1876-1886.

Sholkovitz E., Herbold C. and Charette M. (2003) An automated dye-dilution based seepage meter for time-series measurement of submarine groundwater discharge. Limnol. Oceanogr.: Methods 1, 16-28.

Slater J. M. and Capone D. G. (1987) Denitrification in aquifer soil and nearshore marine sediments influenced by groundwater nitrate. Appl. Environ. Microbiol. 53, 1292-1297.

Slomp C. P., Malschaert J. F. P. and van Raaphorst W. (1998) The role of sorption in sediment-water exchange of phosphate in North Sea continental margin sediments. Limnol. Oceanogr. 43, 832-846.

Slomp C. P. and Van Cappellen P. (2004) Nutrient inputs to the coastal ocean through submarine groundwater discharge: controls and potential impact. J. Hydrol. 295, 64-86.

Spiteri C., Slomp C. P., Tuncay K. and Meile C. (2008) Modeling biogeochemical processes in subterranean estuaries: the effect of flow dynamics and redox conditions on submarine groundwater discharge. Water Resour. Res. 44, W02430. doi:10.1029/ 2008WR006997.

Spiteri C., Regnier P., Slomp C. P. and Charette M. A. (2006) pHDependent iron oxide precipitation in a subterranean estuary. J. Geochem. Explor. 88, 399-403.

Stieglitz T. (2005) Submarine groundwater discharge into the nearshore zone of the Great Barrier Reef, Australia. Mar. Pollut. Bull. 51, 51-59.

Talbot J. M., Kroeger K. D., Rago A., Allen M. C. and Charette M. A. (2003) Nitrogen flux and speciation through the subterranean estuary of Waquoit Bay, Massachusetts. Biol. Bull. 205, 244-245.

Testa J. M., Charette M. A., Sholkovitz E. R., Allen M. C., Rago A. and Herbold C. W. (2002) Dissolved iron cycling in the subterranean estuary of a coastal bay: Waquoit Bay, Massachusetts. Biol. Bull. 203, 255-256.

Ullman W. J., Chang B., Miller D. C. and Madsen J. A. (2003) Groundwater mixing, nutrient diagenesis, and discharges across a sandy beachface, Cape Henlopen, Delaware (USA). Estuar. Coast. Shelf Sci. 57, 539-552.

Valiela I., Foreman K., LaMontagne M., Hersh D., Costa J., Peckol P., DeMeo-Andreson B., D'Avanzo C., Babione M., Sham C., Brawley J. and Lajtha K. (1992) Couplings of watersheds and coastal waters: sources and consequences of nutrient enrichment in Waquoit Bay, Massachusetts. Estuaries 15(4), 443-457. 
Valiela I., Bowen J. L. and Kroeger K. D. (2002) Assessment of models for estimation of land-derived nitrogen to shallows estuaries. Appl. Geochem. 17, 935-953.

Van Cappellen P. and Wang Y. (1995) Metal cycling in surface sediments: modeling the interplay of transport and reaction. In Metal Contaminated Sediments (ed. H. E. Allen). Ann Arbor Press, Chelsea, Michigan, pp. 21-62.

Wang Y. and Van Cappellen P. (1996) A multi-component reaction-transport model of early diagenesis: application to redox cycling in coastal marine sediments. Geochim. Cosmochim. Acta 60, 2993-3014.

Wilhelm S. R., Schiff S. L. and Cherry J. A. (1994) Chemical fate and transport in a domestic septic system: unsaturated and saturated zone geochemistry. Environ. Toxicol. Chem. 13(2), 193-203.

Associate editor: Timothy J. Shaw 